\title{
Cellular RNA Hubs: Friends and Foes of Plant Viruses
}

\author{
Min Xu, ${ }^{1,2}$ Magdalena J. Mazur, ${ }^{2}$ Xiaorong Tao, ${ }^{1, \dagger}$ and Richard Kormelink ${ }^{2, \dagger}$ \\ ${ }^{1}$ Key Laboratory of Integrated Management of Crop Diseases and Pests, Ministry of Education, Department of Plant Pathology, \\ Nanjing Agricultural University, Nanjing 210095, China \\ ${ }^{2}$ Laboratory of Virology, Department of Plant Sciences, Wageningen University \& Research, Droevendaalsesteeg 1, 6708PB \\ Wageningen, The Netherlands
}

Accepted 14 August 2019.

\begin{abstract}
RNA granules are dynamic cellular foci that are widely spread in eukaryotic cells and play essential roles in cell growth and development, and immune and stress responses. Different types of granules can be distinguished, each with a specific function and playing a role in, for example, RNA transcription, modification, processing, decay, translation, and arrest. By means of communication and exchange of (shared) components, they form a large regulatory network in cells. Viruses have been reported to interact with one or more of these either cytoplasmic or nuclear granules, and act either proviral, to enable and support viral infection and facilitate viral movement, or antiviral, protecting or clearing hosts from viral infection. This review describes an overview and recent progress on cytoplasmic and nuclear RNA granules and their interplay with virus infection, first in animal systems and as a prelude to the status and current developments on plant viruses, which have been less well studied on this thus far.
\end{abstract}

Keywords: Cajal bodies, COP1 bodies, GW-bodies, GW182bodies, RNA granules, RNA processing bodies, P-body, photobodies nucleolus, plant responses to pathogens, plant virus, SG, siRNA bodies, stress granules, virus-plant interactions

Eukaryotic cells have organized cellular RNA synthesis and their modification, translation, and degradation in various cytoplasmic and nuclear RNA granules. The most well-known RNA granules are the cytoplasmic stress granules (SGs), processing bodies (P-bodies), and nuclear Cajal bodies (CBs). RNA granules are defined as structures containing ribonucleoprotein (RNP) complexes, which play key roles in gene expression regulation, RNA turnover, and storage or degradation under different stress conditions (Anderson and Kedersha 2009). However, in the cytoplasm, in addition to P-bodies and SGs, small-interfering RNA (siRNA) bodies, neuronal bodies (in neuron cells), and exosome bodies also are present (White and Lloyd 2012). The nucleus comprises other distinct bodies as well, such as the nucleolus, nuclear speckles (NSs), nuclear stress bodies, transcription factories, histone locus bodies, paraspeckles, animal- or human-specific promyelocytic leukemia protein (PML) bodies, and photobodies present only in plant cells (Dundr and Misteli 2010; Morimoto and Boerkoel

${ }^{\dagger}$ Corresponding authors: X. Tao; taoxiaorong@njau.edu.cn; and R. Kormelink richard.kormelink@wur.nl

The author(s) declare no conflict of interest.

(C) 2020 The American Phytopathological Society
2013). All of these RNA granules do not function individually but, rather, are part of finely tuned cellular regulatory network.

Viruses pose a stress condition on cells and trigger or modulate the formation of such RNA granules, often for their own benefit. For example, in response to hepatitis $\mathrm{C}$ virus, not only is assembly of SGs induced but also the virus, by means of two viral replication proteins, interacts with SG component GTPase-activating protein (SH3 domain) binding protein (G3BP) 1, suggesting a direct (proviral) role of SGs in viral infection (Garaigorta et al. 2012; Li et al. 2013; Poblete-Durán et al. 2016). During rubella virus infection, SG formation is induced to facilitate viral encapsidation (Matthews and Frey 2012; Poblete-Durán et al. 2016). Although viral proteins often interact with SG components for their own benefits, as was nicely described in several recent review articles (Pager et al. 2013; White and Lloyd 2012), SG may also act antivirally. In order to establish a viral infection under such condition, viruses must counter to defend against host defense responses by, for instance, inhibiting SG formation.

The development of laser-scanning confocal microscopy and fluorescence techniques has greatly boosted and facilitated visualization and studies on the subcellular granules and their relationships during the past two decades. The importance of RNA granules in cell development and their roles in viral infection (to some extent still being elusive) has attracted increasing numbers of virologists to study the relationships between RNA granules and virus infection. Within the past decade, numerous studies have been performed in animal virus cell systems and readers are referred to some good and detailed reviews on this topic for further reading (Beckham and Parker 2008; Reineke and Lloyd 2013; Tsai and Lloyd 2014; White and Lloyd 2012). Studies in plant virus-host systems, however, are still more limited. In this review, a brief overview will be presented on what is known from animal systems and their most recent developments, with a description (of commonalities and differences) and outlook on the situation with plant viruses. Regardless of whether animal or plant viruses are involved, it is expected that knowledge of this subject and the identification of pro- and antiviral host factors may contribute, in the long term, to the development of strategies to combat viral diseases.

\section{CYTOPLASMIC RNA GRANULES}

RNA P-bodies, GW-bodies, and SGs: Storage sites for "silenced" mRNA but distinct in their function and composition.

In animals and yeast. During the RNA life cycle, various mechanisms regulate the level and rate of gene expression and 
RNA turnover. Once mRNAs are produced in the nucleus, their export into the cytoplasm and recruitment of the translation initiation complex initiates protein synthesis. If not, (bulk) RNAs or mRNAs face aggregation and storage in SGs, or assemble into P-bodies for further degradation (Kedersha et al. 2005). SGs and P-bodies are cytoplasmic structures with distinct functions in the mRNA triage. Although both structures share several proteins and components and coordinate during stress conditions, P-bodies are constitutively present whereas SGs can only be observed during stress conditions. On some occasions, P-body and SG component proteins also function in other molecular processes such as splicing, signaling, and development (Anderson and Kedersha 2008). SGs are formed by macromolecular assemblies, stalling translation preinitiation factors in response to stress conditions (Anderson and Kedersha 2009). Under normal conditions, mRNAs are delivered from nucleus to cytoplasm. Following the binding of eIF4E to the 5'Cap structure, the translation initiation complex and ribosome are recruited and mRNAs engage in translation, ending up in polysomes when multiple ribosomes translate the mRNA at the same time (Moore 2005). In animal cells, when disassembly of polysomes is initiated by stress, T-cell intracellular antigen (TIA)-1 and TIA-1-related protein (TIAR) links to eIF2 $\alpha$ phosphorylation, which interferes with eIF2 $\alpha$-GDP recycling and compromises the availability of eIF2 $\alpha$-GTP-Met-tRNAiMet during translation. Ribosomal translation is stalled, and transcripts detach and release as circular polyadenylated mRNPs (Kedersha et al. 1999; McInerney et al. 2005). TIA-1, TIAR, and other mRNA binding proteins, including tristetraprolin (TTP), BRF1, FMRP, FXR1, CPEB, G3BP, and survival of motor neuron (SMN), mediate primary aggregation of SGs. Interactions between these proteins promote secondary aggregation of mRNPs and assemble into microscopically visible SGs. Next, SGs integrate other aspects of cellular metabolism and deliver signals to downstream pathways. In the longer term, stored mRNAs may reinitiate in translation or become degraded (Anderson and Kedersha 2008).

P-bodies have a different function in RNA turnover and contain components of the mRNA decay machinery whose assembly is dependent on the pool of untranslated mRNA (Liu et al. 2005; Pillai et al. 2005; Teixeira et al. 2005). Apart from mRNA turnover, P-bodies are also involved in $5^{\prime}$ to $3^{\prime}$ RNA decay, RNA transportation and stabilization, and the RNA interference pathway (Anderson and Kedersha 2009; Jakymiw et al. 2005; Moser et al. 2007). Several proteins are essential and unique to P-bodies, which include decapping enzymes 1 and 2 (Dcp1 and Dcp2), activators of decapping (Dhh1p, Pat1p, and Lsm1-7p), RNA DEAD-box helicase 6 (DDX6), and the 5' to 3' exonuclease Xrn1p, while P-bodies generally lack translation factors (Eulalio et al. 2007; Ingelfinger et al. 2002; LykkeAndersen 2002; van Dijk et al. 2002). In eukaryotes, massive mRNAs undergo decay by a pathway that is initiated by poly(A)tail shortening. Deadenylation of mRNAs is a prerequisite of P-body formation, and most mRNAs within P-bodies lack (long) poly (A) tails (Kulkarni et al. 2010).

In P-bodies, the $5^{\prime}$ cap structure is removed from these molecules by Dcp2, leading to the generation of mRNAs that expose a $5^{\prime}$ monophosphate and become further processed by XRN1, a cytoplasmic exoribonuclease (Xrn) for $5^{\prime}$ to $3^{\prime}$ mRNA decay (Eulalio et al. 2007). Depletion of decapping coactivators such as DCP1 and Lsm1-7 cause the loss of P-bodies. Although RNAs or mRNAs mostly end up in P-bodies for turnover or decay, studies have shown that mRNAs can also go back into translation (Coller and Parker 2005; Sheth and Parker 2003; Tharun et al. 2005). mRNAs that experience reinitiation first go to SGs before eventually entering polysomes (Stoecklin and Kedersha 2013). During mRNA translation, SGs and P-bodies cooperate in structures to maintain proper translation rates (Parker and Sheth 2007).
In both mammalian cells and yeast cells, P-bodies and SGs have been observed to form docking stages (Brengues et al. 2005; Eulalio et al. 2007), during which RNA and protein components exchange. This also explains why some proteins were localized in both P-bodies and SGs. P-bodies contain RCK/p54, CPEB, XRN1, eIF4E, Fas-activated serine/threonine phosphoprotein, and TTP proteins, which will relocate to SGs under stress. Conversely, TIA-1 and TIAR proteins are known to predominantly exist in SGs but have also been found in Pbodies (Eulalio et al. 2007). For this reason, marker proteins that specifically localize to only one of those granules are used to distinguish between P-bodies and SGs during cell biology studies. Translation factors such as eIF3b, eIF4A, and eIF4G and RNA-binding proteins (RBPs) such as poly(A)-binding protein (PABP) and G3BP can be used as specific markers for SGs, while components of the cytoplasmic RNA degradation machinery such as Dcp2, Dcp1, or Hedls serve as reliable marker proteins for P-bodies (Stoecklin and Kedersha 2013). Under different stress conditions, cells that were cotransfected with RFP-DCP1a (P-body marker) and green fluorescent protein (GFP)-TIA-1 (SG marker) show frequent association of SGs with one or more P-bodies. TTP and BRF1 proteins, which are RBPs that promote mRNA decay, regulate the dynamic interactions between SGs and P-bodies (Kedersha et al. 2005).

In addition to deadenylation of mRNA, organisms have additional pathways that remove RNAs away from active translation and finally toward P-bodies for degradation. The most well known are the nonsense-mediated decay (NMD) pathway and the microRNA (miRNA)- and siRNA-mediated genesilencing pathways. Although these pathways involve a different process to determine the fate of their target, based on mRNP dynamics, they rely on the downstream P-bodies for degradation.

The NMD pathway recognizes mRNAs with aberrant termination codons (TCs) and targets them into P-bodies. Aberrant TCs have multiple features such as natural premature TCs (PTCs); the nucleotide immediately following the stop codon; and the sequences, length, and associated proteins of the $3^{\prime}$ untranslated region (UTR). These features may result in differences in translation termination or decay of mRNAs (Shyu et al. 2008). In yeast, three conserved proteins, UPF1 to -3 (standing for ATP-dependent RNA helicase upstream frameshift-1 to -3), are functional in the recognition of PTCs, of which UPF1 is the most abundant or prominent one, and sufficient for targeting mRNAs to P-bodies, while UPF2 and -3 are downstream triggers for P-body targeting (Eulalio et al. 2007; Sheth and Parker 2006). Serine and threonine protein kinases SMG1 and SMG5-7 are also conserved NMD effectors that localize to Pbodies (Fukuhara et al. 2005; Unterholzner and Izaurralde 2004). Furthermore, human SMG7 recruits the surveillancecomplex protein UPF1 and SMG5 to P-bodies (Unterholzner and Izaurralde 2004). The NMD pathway mainly serves to recognize and eliminate PTC-containing mRNAs to prevent the production of aberrant and potentially toxic proteins. However, and interestingly, UPF1 is also able to target normal mRNAs to P-bodies (Sheth and Parker 2006) and a growing amount of evidence indicates a role of UPF1 in various other RNA decay pathways, and that it also can function as a E3-ubiquitin ligase to play a role in protein decay (Feng et al. 2017; Kim and Maquat 2019).

miRNAs and siRNAs are hallmarks of RNA interference (RNAi) or RNA silencing and consist of (endogenous) RNA duplex molecules 21 nucleotides (nt) in size that are processed from double-stranded (ds)RNA molecules by RNaseIII-like enzymes called Dicer. Both types of small RNAs play a major role in the regulation of gene expression via RNAi (also referred to as RNA silencing). miRNAs originate from noncoding 
transcripts that fold in relatively short, imperfect dsRNA hairpin loop structures (pri-miRNA) and are processed into premiRNAs. These are transported from the nucleus into the cytoplasm for further maturation into miRNAs. siRNAs are produced from relatively long, perfect dsRNA molecules. Although the biogenesis of miRNAs and siRNAs differs, they are structurally and functional similar. From these duplex molecules, one strand associates with Argonaute (AGO) protein to activate an RNA-induced silencing complex (RISC). Although miRNA-loaded RISC complexes repress translation or trigger degradation of target mRNAs (Eulalio et al. 2008), siRNAs strictly target mRNAs with sequence complementarity for cleavage and degradation (Hannon 2002).

Proteins that govern miRNA-mediated silencing such as GW-182/Gw and AGO1 are often associated with P-bodies of higher eukaryotic organisms (Jakymiw et al. 2005; Pillai et al. 2005). For this reason, GW-containing bodies (also referred to as GW-bodies) have long been thought to be similar to Pbodies. However, several reports have indicated that GWbodies have different dynamics than P-bodies. Like P-bodies, GW-bodies contain factors required for RNA decapping and decay such as Dcp2, LSm-4, and Xrn1 (Behm-Ansmant et al. 2006; Eystathioy et al. 2003) but, in contrast, they have been observed to lack decapping factors such as Dcp1 and Me31B, and have also been observed in the nucleus (Patel et al. 2016).

GW-182 is a scaffold for protein complexes involved in miRNA-mediated silencing of RNA targets. GW-182 contains an N-terminal domain with $\mathrm{GW}$ and WG motifs to enable binding to AGO proteins, a ubiquitin-associated domain, and a silencing domain that contains an RNA recognition motif (RRM) and CCR4-NOT interacting motifs. GW-182 associates with a unique subset of mRNAs (Eystathioy et al. 2002). Although the mechanism on how GW-182 causes translational repression and miRNA-mediated target degradation is still not yet fully understood, the protein interacts with a specific subset of AGO proteins involved in the miRNA pathway: the cytoplasmic PABP, PAN2-AND3, and CCR4-NOT deadenylase complexes (Behm-Ansmant et al. 2006). The W motifs of GW182 recruit deadenylase complexes and depend on CCR4-NOT for poly(A) ${ }^{-}$mRNA repression but no direct link has been observed between recruitment of CCR4-NOT and mRNA repression (Chekulaeva et al. 2011). In animals, CAF1 or NOT regulate the expression of most $\mathrm{AGO} 1$ targets and indicate that deadenylation by the CAF1-CCR4-NOT1 complex is a widespread effect of miRNA regulation (Eulalio et al. 2009). MiRNA-mediated mRNA degradation involves alteration of mRNP composition or conformation, and does not result from direct interference with the binding and function of ribosomal units to mRNAs. Overexpression of Dcp1a and G3BP1 is observed to induce P-bodies and SGs. Although the induction of these granules inhibits protein synthesis, induced GW-182 bodies do not (X. Wang et al. 2017). siRNAs and miRNAs can function in the absence of detectable P-bodies and their accumulation together with AGO proteins and mRNA targets in GW-bodies is the consequence rather than the cause of silencing (Pauley et al. 2006). Furthermore, in contrast to miRNAs, siRNAs may affect mRNA metabolism and reduce the amount of mRNA directed to GW-bodies and, thereby, could lead to the disappearance of GW-bodies (Serman et al. 2007). Disruption of GW-bodies impairs RNA interference in mammals (Jakymiw et al. 2005).

Altogether, this supports the idea that GW-bodies are (functionally) distinct from P-bodies, and likely play a role as repository for translationally silenced RNAs but not in active translational silencing (Patel et al. 2016). Another distinct and unique feature for GW-182 is the observation that GW-bodies, in contrast to Pbodies and SGs, have also been found in the nucleus.
In plants. It is generally believed that P-bodies and SGs are evolutionary conserved among eukaryotes and in plants to resemble, structurally and functionally, those from animal and yeast systems as described above. Although less research has been performed in plants, studies on these structures have slowly unveiled their roles in plant cells, with essential roles in plant development and immune response (Bhullar et al. 2017; Dong et al. 2016; Meteignier et al. 2016; Xu and Chua 2011). Tobacco plant P-bodies play a role in reprogramming mature cells and reinitiation of the cell division cycle (Bhullar et al. 2017). In Nicotiana benthamiana, responses of dominant resistance $(R)$ genes from the class nucleotide-binding leucine-rich repeat induce dramatic increase in the biogenesis of P-bodies (Meteignier et al. 2016).

In plants, several homologs of animal proteins have been identified with a function in RNA granule formation and gene expression regulation, sometimes differently named though.

In Arabidopsis thaliana, the major components of the decapping complex are Dcp1, Dcp2, and varicose (VCS), proteins which present the homologs of Dcp1, Dcp2, and HEDLS/GE-1 protein, respectively, from animal systems (Weber et al. 2008; Xu et al. 2006). Later, A. thaliana (At)DCP5 was identified as another component that complexes to Dcp1 and Dcp2 and is required for decapping, translational repression, and P-body formation (Xu and Chua 2009).

The triple RRM OLIGOURIDYLATE BINDING PROTEIN 1 (UBP1) protein exhibits highest amino acid similarity to the animal SG component TIA1/Rs. Additional triple RRM proteins with similarity to TIA1 are RBP46 and RBP47 and PAB protein. During a stress response of hypoxia in Arabidopsis, UBP1C has been observed to dynamically and reversibly aggregate into cytoplasmic granules that contain poly(A)+ RNA and PABP, and are referred to as UBP1 SGs (Sorenson and Bailey-Serres 2014). UBP1 likely functions in the same manner as mammalian TIA-1 in the sequestration of mRNA in SGs. Like TIA1 SGs, formed upon impairment of translation by phosphorylation of eIF2 $\alpha$, formation of UBP1 SG in Arabidopsis seems energy related, being promoted by, for example, arsenite and KCN (Sorenson and Bailey-Serres 2014).

Recently, a plant homolog of SG-component G3BP has been cloned from Arabidopsis (Krapp et al. 2017). Under stress conditions, AtG3BP appears in a granular phenotype and colocalizes with TZF1, a protein that, as in mammalians cells, colocalizes with SGs and P-body components and also binds both DNA and RNA (Krapp et al. 2017; Lykke-Andersen and Wagner 2005; Pomeranz et al. 2010). Cycloheximide treatments followed by heat stress abolish AtG3BP granule formation, similar to what also has been observed with UBP1 granules.

In addition to the core protein homologs of P-bodies and SGs, more proteins have been identified in plants and implicated as having a role in these structures. Tudor staphylococcal nuclease (TSN or Tudor-SN; also known as SND1) is a protein that is indispensable in stress tolerance. TSN1 and TSN2 colocalize with SGs in A. thaliana protoplasts and stably associate with SGs and P-bodies (Gutierrez-Beltran et al. 2015). ANGUSTIFOLIA, a plant homolog of CtBP/BARS, colocalizes with several mRNP granule markers to SGs and regulates their formation in a stress-dependent manner (Bhasin and Hülskamp 2017). VASCULAR PLANT ONE-ZINC FINGER protein colocalizes with both SGs and P-bodies under heat stress conditions and functions as a transcriptional repressor of DREB2A in Arabidopsis. In contrast to the situation in mammals, where movement of P-bodies involves microtubuli, in plants, their movement is dependent on actin through AtDCP1 binding to myosin XI-K (Steffens et al. 2014).

UPF1, the key factor for the assembly of the NMD core complex, is conserved across all eukaryotes and also found in 
plants. A recent study (2018) in Arabidopsis revealed that more than $50 \%$ of the proteins that interact and colocalize with UPF1 have also been observed to copurify with Dcp5 (Chicois et al. 2018). Among those, terminal nucleotidyl transferase; ribonucleases; and RNA helicases RH6, RH8 and RH12, three Arabidopsis homologs of the DDX6 in animals, are required for P-body formation (Chicois et al. 2018). UPF1 also colocalizes with typical P-body components such as LSM14A and DCP5, altogether indicating that also in plants RNA degradation and translational repression extensively interact.

For GW-182, elementary to the formation of GW-bodies in animals and insects and involved in miRNA-mediated silencing of RNA targets, no homologs have been found thus far in plants and fungi (Behm-Ansmant et al. 2006; Braun et al. 2013; Eulalio et al. 2009). However, proteins are found containing GW-repeats that interact with AGOs in a manner similar to GW-182 proteins. In A. thaliana, those motifs are found, for example, in NRPE1, a subunit of polymerase IV (involved in transcription of noncoding RNAs that are required for transcriptional gene silencing via the RNA-directed DNA methylation $[\mathrm{RdDM}]$ pathway) (e.g., of transposable elements) (Zhou and Law 2015) and SPT5-like transcription elongation factor. Both proteins are known to interact with AGO4 (Bies-Etheve et al. 2009; Lahmy et al. 2009), which is required to mediate transcriptional gene silencing in plants. Another protein containing GW-repeats is silencing defective 3 (SDE3), a putative RNA helicase and homolog of the mammalian MoV10 helicase, that binds to AGO proteins and assists in the amplification of posttranscriptional gene silencing (PTGS) by RNA-dependent RNA polymerases 6 (RDR6, see below) (Garcia et al. 2012).

In contrast to the absence of typical GW-bodies, plant cells contain siRNA bodies that are absent from animal cells and required for the amplification of RNAi. This involves hostencoded RDRs. In A. thaliana, six RDRs are found, of which RDR1, -2, and - 6 have a well-established role in the amplification of RNAi. RDR3, -4 , and -5 have not been assigned any function yet, although, recently, a homolog from tomato has been shown to be involved in enhancing transcriptional gene silencing (Butterbach et al. 2014). Aberrant RNAs, resulting from activated RISC-AGO cleavage, may enter P-bodies for decay but, instead, can also be converted by RDRs into dsRNA and subsequently processed into a population of secondary siRNAs. This process occurs in siRNA bodies, cytoplasmic granules which contain suppressor of gene silencing 3 (SGS3) and RDR6 (also named as SGS3- and RDR6-bodies) and are different from P-bodies (Kumakura et al. 2009). P-bodies and siRNA bodies both compete for the same RNA substrate. When P-bodies are functionally compromised, aberrant RNAs may enter siRNA bodies, leading to higher production of secondary siRNAs and concomitant stronger RNAi response. Conversely, a knock down of RDR6 leads to a reduced RNAi response and a stronger induction of P-bodies and degradation of aberrant RNAs (Martínez de Alba et al. 2015; Thran et al. 2012; Tsuzuki et al. 2017).

In plants, siRNA or miRNA associate with AGO proteins and target mRNA to accomplish endonucleolytic cleavage. This process is catalyzed by the C-terminal PIWI domain of AGO proteins. Afterward, small fragments of RNA products enter the general mRNA-decay pathway (Lingel and Sattler 2005; Orban and Izaurralde 2005). In Arabidopsis, mRNA cleavage products experience 3' removal by XRN4 proteins (Souret et al. 2004).

\section{NUCLEAR RNA GRANULES}

The nucleus is the predominant compartment for cell RNA processing and metabolism, processes that are contained within nuclear RNA granule structures. Thus far, several different nuclear RNA granules have been identified, and among the most prominent are nucleoli, CBs, spliceosomes, speckles, and dicing bodies. They are nuclear condensation centers for RNA molecules and proteins that are involved in processes such as RNA splicing, ribosomal RNA (rRNA) transcription, small nuclear RNPs (snRNPs) biogenesis and maturation, miRNA- or siRNA-mediated gene silencing, and stress responses. Nuclear RNA granules are highly dynamic, and their formation can be a result of external stimuli such as various stress conditions (Boulon et al. 2010).

The nucleolus is the biggest and the most prominent compartment of the nucleus. This membraneless organelle is organized into the fibrillar center, the dense fibrillar component, and the granular component. It primarily serves as a factory for rRNA synthesis by RNA polymerase I transcription, rRNA processing, and ribosome assembly (Stępiński 2014). However, the presence of proteins involved in many other aspects of molecular cell biology such as cell cycle regulation, development, telomerase activity, gene silencing, and biotic or abiotic stress signaling suggests further roles for the nucleolus (Dubois and Boisvert 2016; Pendle et al. 2005). One of these processes identified that links nucleolus and cytoplasmic P-bodies is the mRNA quality-control pathway by NMD. Although the NMD pathway in animal cells is associated with cytoplasmic Pbodies, the presence of aberrant mRNA transcripts and NMD proteins UPF2 and UPF3 and exon joining complex (EJC) in the nucleoli of plant cells indicates their involvement in NMD as well (Kim et al. 2007b; Pendle et al. 2005).

Another type of the most well studied nuclear granules are the $\mathrm{CBs}$, also known as coiled bodies. $\mathrm{CBs}$ are very dynamic structures; the size and the number of the CBs depend on the type, cycle stage, and transcriptional activity of the cell (Boudonck et al. 1998). They translocate within the nucleus and locate in the nucleoplasm and in the nucleolar periphery but also can enter the nucleolus (Boudonck et al. 1999). Nucleolus and $\mathrm{CBs}$ are not only physically but also functionally connected. Both structures share structurally important proteins such as fibrillarin (FIB) or coilin, an essential scaffold protein for CB formation (Collier et al. 2006; Trinkle-Mulcahy and Sleeman 2017). Also, they participate in the assembly and processing of small nucleolar RNPs and formation of spliceosomal snRNPs, core particles that control premRNA splicing (Trinkle-Mulcahy and Sleeman 2017).

One main process that is intrinsically controlled by $\mathrm{CBs}$ is the formation of spliceosomal snRNPs, RNA-protein complexes that bind unmodified premRNA to form a spliceosome. Therefore, CBs contain a number of proteins vital for splicing of premRNA (such as the SMN, Sm, or Gemin proteins, well characterized in animal cells) (Love et al. 2017). Newly transcribed uridine-rich $\mathrm{U} 1, \mathrm{U} 2, \mathrm{U} 4$, and U5 snRNPs are exported to the cytoplasm and, together with the core Sm proteins, assemble into SMN protein complexes. Most U snRNPs assemble in the cytoplasm and spatially organize in the cytoplasm in discrete structures, which also have been referred to as Ubodies. U-bodies consistently associate to P-bodies and disruption of the latter affects U-body organization, indicating that $\mathrm{P}$-bodies and U-bodies cooperate in the regulating aspects of snRNP metabolism (Liu and Gall 2007).

Evidence is accumulating that, in addition to having a major role in RNA metabolism and snRPN biogenesis, nucleolusassociated CBs also play a role in RNA silencing by siRNA and miRNA processing. In Arabidopsis, a pathway generating 24-nt siRNAs is responsible for RdDM and transcriptional silencing, involving a number of proteins such as RNA polymerase IV (Pol IV), RDR2, Dicer-like 3 (DCL3), and AGO4. Interestingly, RDR2, DCL3, and AGO4 are localized with one another in 
nucleolus-associated loci, which also colocalize with $\mathrm{CB}$ markers ( $\mathrm{Li}$ et al. 2006; Pontes et al. 2006). Moreover, two major proteins involved in the miRNA pathway, DCL1 and hyponastic leaves 1(HYL1) (Kurihara et al. 2006), also were found in these DCL3-containing siRNA foci, indicating that CBs emerge as siRNA and miRNA processing centers (Fujioka et al. 2007; Pontes and Pikaard 2008). It is, however, interesting to note that the nucleolar periphery-localized foci of DCL1 and HYL1 were previously referred to as dicing bodies, distinct from CBs because they lack coilin (Fang and Spector 2007; Song et al. 2007).

In addition to the nucleolus and $\mathrm{CB}$, few other nuclear bodies are reported, some with similarity to $\mathrm{CB}$. The histone locus body (HLB) is a subnuclear body that resembles CB physically (in shape and size) and functionally, because they share proteins and RNA molecules (Nizami et al. 2010a). Although a substantial part of HLB contains coilin, in contrast to CB, HLB does not require coilin for its assembly (Nizami et al. 2010b). HLBs are known to be involved in the processing of histone premRNAs (Nizami et al. 2010b).

There are other nuclear bodies that are shown to accumulate RNA of which the precise function remains to be determined (Mao et al. 2011). NSs present sites for storage and modification of splicing factors, which indicates their role in the coordination of nuclear gene expression regulation. This is supported by the observation that RNA polymerase II transcription occurs nearby NSs (Galganski et al. 2017). Paraspeckles are nuclear bodies that form upon stress and consist of the long noncoding NEAT (nuclear paraspeckle assembly transcript 1) RNA scaffold associated with a large amount of RNA-binding proteins. Therefore, paraspeckles have been suggested to act as a sequestration "sponge" for proteins (Bond and Fox 2009; Fox et al. 2018). Polycomb group bodies (PcGbodies) present atypical nuclear bodies that show up at target genes to modulate their activity by epigenetic regulation of their transcription in eukaryotes. PcG proteins form multiprotein complexes, known as Polycomb repressive complex 1 (PRC1) and Polycomb repressive complex 2 (PRC2), that localize to PcG bodies (del Olmo et al. 2016; Mao et al. 2011; Picó et al. 2015).

\section{RNA GRANULES AND THE INTERPLAY WITH VIRUSES}

There are many excellent reviews that describe the interplay between different cytoplasmic RNA granules and viral infection in animal or yeast systems, involving immunity responses to either inhibit viral accumulation or facilitate viral proteins to accomplish their replication, translation, and movement (Beckham and Parker 2008; Poblete-Durán et al. 2016; Reineke and Lloyd 2013; Tsai and Lloyd 2014; White and Lloyd 2012). Separate articles also have described the involvement of nuclear bodies. Studies on plant virus-granule interaction have just more recently emerged and reviews on cytoplasmic granules and nucleus have separately appeared (Kim et al. 2004; Li et al. 2018; Mäkinen et al. 2017).

Without becoming too extensive, and to give a glimpse of the diversity of interplay, a few examples are given for animal viruses, and readers are referred to some nice reviews for further reading (Lloyd 2015, 2016; Onomoto et al. 2014; PobleteDurán et al. 2016), prior to a more extensive description of the recent progress and current status with plant viruses.

During viral infection of animal cells, SGs are often reported to act either antivirally or provirally. Upon virus infection, interferon-stimulated gene products such as PKR, RNAsensing receptors such as RIG-I and MDA5, RNase L, and OAS have been observed to localize in SGs (Hebner and
Laimins 2006; Okonski and Samuel 2012; Onomoto et al. 2012), but are also found in P-bodies (Hebner and Laimins 2006). Therefore, modulation of SGs and P-bodies may promote viral replication and suppress stress responses or antiviral defense. For example, members of the Togaviridae family such as Semliki forest virus and chikungunya virus (CHIKV) and Flaviviridae family such as West Nile virus (WNV) and Zika virus (ZIKV) encode nonstructural proteins that sequester G3BP and TIA-1 or TIAR, respectively, thereby preventing SG formation and promoting viral replication (Fros et al. 2012; Li et al. 2002; Panas et al. 2012). Later, G3BP was demonstrated to also play a proviral role in CHIKV replication (Scholte et al. 2015). The cellular NMD pathway restricts ZIKV infection, and the viral capsid protein has been shown to interact with UPF1 to target the protein for proteasomal degradation and thereby inhibit the NMD pathway (Fontaine et al. 2018). EJC has a role in NMD and both act antivirally to WNV. The EJC protein RBM8A directly binds WNV RNA but the virus is able to counteract NMD and its capsid protein interferes with EJC function and localization (M. Li et al. 2019).

In addition, the nuclear replicating influenza virus inhibits SG formation during viral infection, via inhibition of PKR activity by the NS1 protein (Khaperskyy et al. 2012). Furthermore, the influenza nucleoprotein or viral RNPs have been observed to localize near or at nuclear $\mathrm{CB}$ and PML nuclear bodies (NBs) (Höfer et al. 2017), as well as cytoplasmic Pbodies (J. Li et al. 2019). In the latter case, viral RNPs interacted with the antiviral protein MoV10, a UPF-1 like RNA helicase that facilitates UPF1-mediated RNA degradation, likely for degradation of viral RNA. MoV10 normally localizes to P-bodies and SGs, where it associates with the RISC complex, but is also inhibited by the influenza NS1 protein (J. Li et al. 2019). In contrast to influenza virus, vesicular stomatitis virus induces the phosphorylation of eIF $2 \alpha$ and promotes the assembly of SG-like particles that also contain viral replication proteins and RNA, indicating that these structures play a role in the replication cycle (Dinh et al. 2013). The nucleocapsid protein of Sin Nombre hantavirus (SNV) has been shown to colocalize to P-bodies, from where the virus is postulated to use host cellular mRNAs containing a premature stop codon for cap-snatching to initiate viral genome transcription (Mir et al. 2008).

Recent studies point to the importance of the SUMO pathway in the regulation of type I and -II interferon responses, and PML NBs play a role in the catalysis of SUMOylation together, which strongly suggests a role of PML in antiviral defense. In light of this, it makes sense that virus infections in the past have been reported to modify PML body formation (Scherer and Stamminger 2016).

In addition, plant viruses are reported to interplay with cytoplasmic or nuclear RNA condensations. However, the reason for this interplay sometimes still remains elusive. A schematic overview of the regulatory network of different granules and the interplay with viral proteins and infections is presented in Figure 1. An overview of reported protein interactions of plant viral proteins with cytoplasmic and nuclear granule components is shown in Table 1. In the sections below, these interactions are further discussed, in support of viral infection and RNA accumulation and (systemic) spread, or repression of antiviral host responses.

\section{PLANT VIRUS INTERPLAYS WITH CYTOPLASMIC GRANULES}

A study has shown that $A$. thaliana $60 \mathrm{~S}$ acidic ribosomal protein $\mathrm{P} 0$ is copurified with potato virus A (PVA) viral protein genome-linked (VPg) and RNA-dependent RNA polymerase 
(RdRp) proteins. SGs and nuclear component eIF(iso)4E colocalize with VPg-formed viral granules and P0 as well. P0 and $\operatorname{eIF(iso)4E}$ both enable or enhance the infection process through protection of viral RNA from degradation. Overexpression of $\mathrm{P} 0$ promoted viral translation and required the viral 5' UTR, while inhibition of viral cell-to-cell spread, competing for viral RNAs, also promoted translation by $\mathrm{P} 0$ and eIF(iso)4E (Hafrén et al. 2013). In another study, the helper component (HCPro) of PVA, among others known to act as suppressor of RNA silencing, also induces RNA granules that, in addition to $\mathrm{P} 0$ and $\mathrm{eIF}(\mathrm{iso}) 4$, contain the SG marker UBP1 and P-body marker VCS and is downregulated by VPg. Whereas HCPro and VCS stimulate VPg-promoted translation, UBP1 inhibits this process, indicating that PVA translation and potyviral RNA granules are interrelated (Hafrén et al. 2015).

Turnip mosaic virus (TuMV), another potyvirus, has been observed to induce similar virus-induced granules, and eIF(iso) 4E was shown to interact with VPg which might play a key role in virus replication and translation (Hafrén et al. 2015). Other translation-associated factors such as eukaryotic elongation factor 1- $\alpha$, PABP2, and chaperone heat shock cognate 70-3 protein have been observed in virus-induced vesicles, and a subpopulation of eIF(iso)4E and PAPB2 to shuttle between cytoplasmic granules and nucleus during virus infection, and due to VPg-Pro (Beauchemin et al. 2006; Brengues and Parker 2007). These studies indicate that TuMV might repress host nuclear mRNA translation and use the cytoplasmic translation machinery to accomplish viral RNA synthesis (Beauchemin and Laliberté 2007). Interestingly, eIF4E or eIF(iso)4E is a nuclear-cytoplasmic shuttle protein involved in mRNA translation or storage (functioning in SG formation during stress) and, in different plant species, confers recessive resistance to plant viruses (Wang and Krishnaswamy 2012).

Recently, $\mathrm{m}^{6} \mathrm{~A}$ demethylase ALKBH10B has been identified in Arabidopsis with a role in the RNA biology of viruses. The protein interacts with the coat protein $(\mathrm{CP})$ of alfalfa mosaic virus (AMV) and removes $\mathrm{m}^{6} \mathrm{~A}$ in the AMV RNA genome. Upon silencing of this gene, systemic infection is largely inhibited. In vivo AtALKBH9B localizes to cytoplasmic bodies that perfectly colocalize with siRNA body component SGS3 and NMD component UPF1 and, in $40 \%$ of the cases, with Pbodies component DCP1, suggesting that AtALKBH9B seems to be an intrinsic component of these RNA bodies and able to restrict AMV infection (Martínez-Pérez et al. 2017).

In yeast, the Lsm1p-7p/Pat1p/Dhh1p complex, which catalyzes deadenylation of mRNA and promotes RNA degradation,

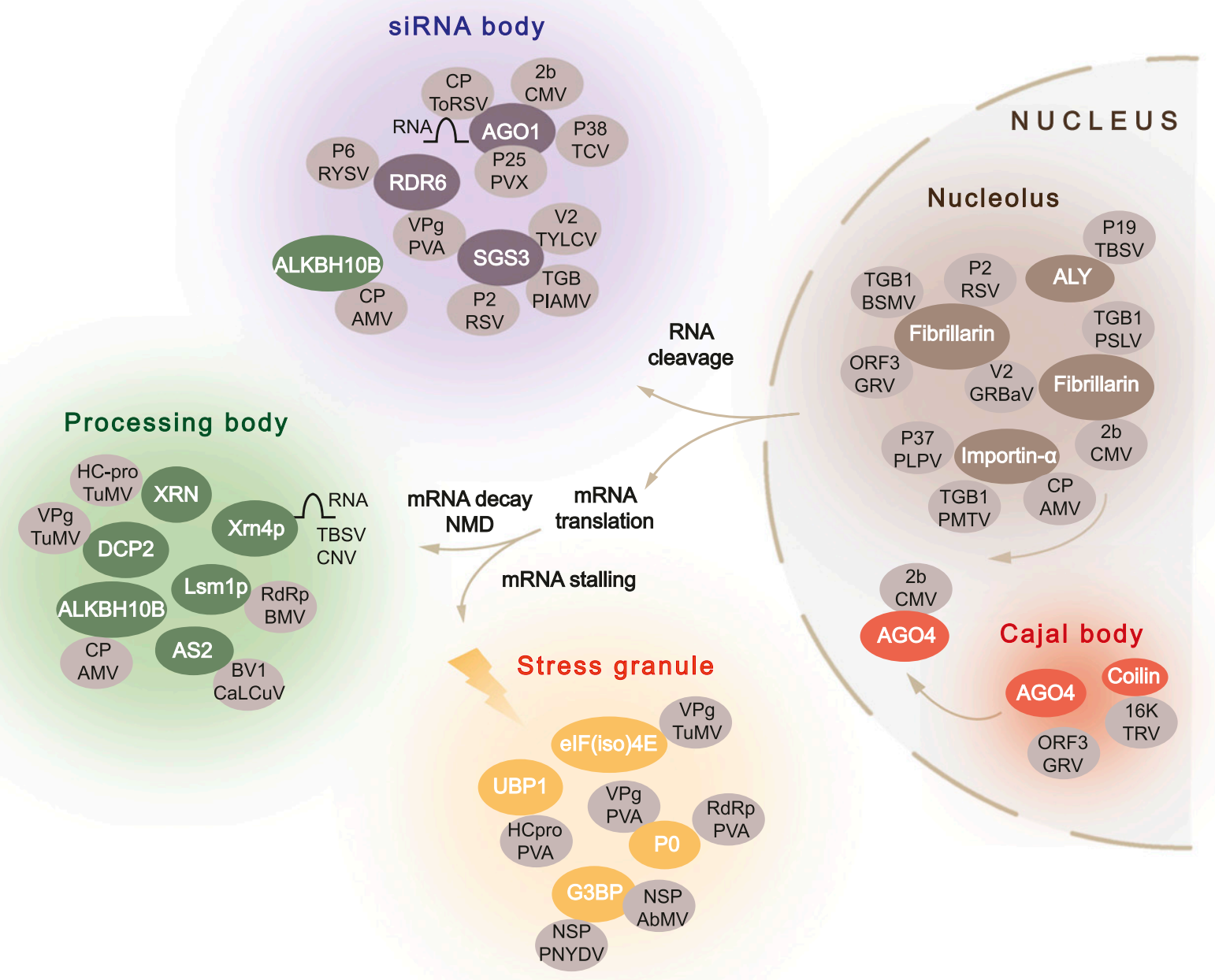

Fig. 1. Schematic diagram on cellular RNA regulatory network hubs and targeting by plant viral proteins. Only viral proteins or RNA that have been identified to interact with proteins from cellular RNA granules are shown. 
has been shown to be pivotal for brome mosaic virus (BMV) replication. BMV RdRp colocalizes with P-body component Lsm $1 \mathrm{p}$ and a deletion mutant of $l s m 7$ has been shown to inhibit viral RNA translation (Noueiry et al. 2003). Furthermore, viral RNAs have been found in P-bodies and their $3^{\prime}$ UTRs to be important for recruiting the decapping complex and switching BMV RNAs from translation into replication (Beckham et al. 2007). The 5' to $3^{\prime}$ Xrn4 is a component of P-body and acts downstream of DCP2, and functionally is similar to yeast xrn1 (Souret et al. 2004). Expression of Xrn4 enhances viral RNA degradation during infection of plants with cucumber necrosis tombusvirus but also promotes the emergence of novel viral variants with different $5^{\prime}$ truncations (Cheng et al. 2007). A similar inhibition is observed after tomato bushy stunt tombusvirus (TBSV) infection (Jaag and Nagy 2009). Conversely, silencing of Xrn4 promotes systemic infection of $N$. benthamiana with TMV (Peng et al. 2011). ASYMMETRIC LEAVES 2 (AS2), a recently identified P-body component, interacts with the cabbage leaf curl virus nuclear shuttle protein BV1 and regulates plant mRNA decapping and degradation. BV1 expression induces AS2 transfer from the nucleus to cytoplasm to activate the decapping machinery. This activation accelerates the host plant mRNA metabolic rate, inhibits siRNA accumulation, and thereby functions as an endogenous suppressor of PTGS, increasing the susceptibility to viral infection (Ye et al. 2015).

Systemic leaves recovering from a tobacco rattle virus (TRV) expressing GFP consistently show an induced increase of Pbody formation, while TRV-GFP RNAs are found associated less with ribosomes, implying a translational arrest. In contrast, in a decapping (DCP2) mutant of Arabidopsis, viral titers are increased, indicating an important role of P-bodies in degradation of viral RNAs (Ma et al. 2015). Infection by TuMV also activates RNA decay, during which 5' to $3^{\prime}$ RNA decay proteins negatively affect TuMV RNA accumulation. VPg and HC-Pro, two RNAi suppressor proteins encoded by TuMV, directly interact with DCP2 and XRN4, respectively, and prevent viral

Table 1. Reported protein interactions between plant RNA granule (and related) components and plant viral proteins, and potential function ${ }^{\mathrm{a}}$

\begin{tabular}{|c|c|c|c|c|}
\hline Components & Viruses & Viral components & Function & References \\
\hline \multicolumn{5}{|l|}{ Cytoplasmic granule } \\
\hline $\begin{array}{l}\text { ASYMMETRIC } \\
\text { LEAVES } 2 \text { (AS2) }\end{array}$ & $\begin{array}{l}\text { Cabbage leaf curl } \\
\text { virus }(\mathrm{CaLCuV})\end{array}$ & BV1 & $\begin{array}{l}\text { Activate DCP2 decapping and } \\
\text { increase viral accumulation }\end{array}$ & $\begin{array}{l}\text { Ghoshal and Sanfaçon 2014; } \\
\text { Ye et al. } 2015\end{array}$ \\
\hline AGO1 & $\begin{array}{l}\text { Tomato ringspot } \\
\text { virus }\end{array}$ & RNAs & Symptom recovery & Ghoshal and Sanfaçon 2014 \\
\hline AGO1 & $\begin{array}{l}\text { Tomato ringspot } \\
\text { virus }\end{array}$ & $\mathrm{CP}$ & $\begin{array}{l}\text { Suppression of (AGO1- } \\
\text { mediated) translational } \\
\text { repression }\end{array}$ & Karran and Sanfaçon 2014 \\
\hline AGO1 & $\begin{array}{l}\text { Turnip crinkle } \\
\text { virus }\end{array}$ & P38 & $\begin{array}{l}\text { Mimic AGO-binding GW- } \\
\text { repeat proteins and } \\
\text { suppression of host } \\
\text { silencing }\end{array}$ & Azevedo et al. 2010 \\
\hline AGO1 & $\begin{array}{l}\text { Potato virus X } \\
\text { (PVX) }\end{array}$ & $\mathrm{P} 25$ & AGO1 degradation & Chiu et al. 2010 \\
\hline AGO1 & $\begin{array}{l}\text { Beet western } \\
\text { yellows virus }\end{array}$ & P0 & $\begin{array}{l}\text { P0-mediated } \\
\text { suppression/degradation of } \\
\text { AGO1 }\end{array}$ & $\begin{array}{l}\text { Baumberger et al. 2007; } \\
\text { Bortolamiol et al. } 2007\end{array}$ \\
\hline AGO1 & $\begin{array}{l}\text { Cucumber mosaic } \\
\text { virus (CMV) }\end{array}$ & $2 b$ & Suppression of RNA silencing & $\begin{array}{l}\text { Zhang et al. 2006; } \\
\text { Zhang et al. } 2017\end{array}$ \\
\hline $\begin{array}{l}5^{\prime}-3^{\prime} \text { exoribonuclease } \\
\text { AtXrn } 4 p\end{array}$ & $\begin{array}{l}\text { Tomato bushy } \\
\text { stunt (TBSV) }\end{array}$ & Viral RNAs & Viral RNA degradation & Jaag and Nagy 2009 \\
\hline $\begin{array}{l}5^{\prime}-3^{\prime} \text { exoribonuclease } \\
\text { AtXrn } 4 p\end{array}$ & $\begin{array}{l}\text { Cucumber } \\
\text { necrosis virus } \\
\text { (CNV) }\end{array}$ & Viral RNAs & $\begin{array}{l}\text { Emergence of novel viral } \\
\text { variants }\end{array}$ & Cheng et al. 2007 \\
\hline NbXrn4/AtXrn4 & $\begin{array}{l}\text { Turnip mosaic } \\
\text { virus (TuMV) }\end{array}$ & HC-Pro & Suppression of XRN4 activity & Li and Wang 2018 \\
\hline $\mathrm{NbDCP} 2$ & $\begin{array}{l}\text { Turnip mosaic } \\
\text { virus (TuMV) }\end{array}$ & VPg & $\begin{array}{l}\text { Interferes with DCP1-DCP2 } \\
\text { complex formation required } \\
\text { for RNA decay }\end{array}$ & Li and Wang 2018 \\
\hline Ribosomal P0 & $\begin{array}{l}\text { Potato virus A } \\
\text { (PVA) }\end{array}$ & VPg and RdRp & $\begin{array}{l}\text { Enhance viral RNA } \\
\text { translation }\end{array}$ & Hafrén et al. 2013 \\
\hline eIF(iso)4E & $\begin{array}{l}\text { Potato virus A } \\
\text { (PVA) }\end{array}$ & VPg & $\begin{array}{l}\text { Enhance viral RNA } \\
\text { translation }\end{array}$ & Hafrén et al. 2013, 2015 \\
\hline eEF1A & $\begin{array}{l}\text { Turnip mosaic } \\
\text { virus (TuMV) }\end{array}$ & RdRp, VPg-protease & Replication and translation & $\begin{array}{l}\text { Beauchemin et al. 2006; } \\
\text { Thivierge et al. } 2008\end{array}$ \\
\hline $\begin{array}{l}\text { Exoribonuclease } \\
\text { Rrp6/a small } \alpha \text {-heat } \\
\text { shock protein }\end{array}$ & Potyvirus & VPg and HCpro & Infectivity & Freire 2014 \\
\hline AtG3BP & $\begin{array}{r}\text { Abutilon mosaic } \\
\text { virus (AbMV) }\end{array}$ & NSP & Unclear & Krapp et al. 2017 \\
\hline AtG3BP & $\begin{array}{l}\text { Pea necrotic } \\
\text { yellow dwarf } \\
\text { virus (PNYDV) }\end{array}$ & NSP & Unclear & Krapp et al. 2017 \\
\hline SGS3/RDR6 & $\begin{array}{l}\text { Potato virus A } \\
\text { (PVA) }\end{array}$ & Vpg & $\begin{array}{l}\text { Suppression of sense- } \\
\text { mediated RNA silencing }\end{array}$ & Rajamäki et al. 2014 \\
\hline SGS3 & $\begin{array}{l}\text { Tomato yellow } \\
\text { leaf curl virus } \\
\text { (TYLCV) }\end{array}$ & $\mathrm{V} 2$ & $\begin{array}{l}\text { Interfere with sense RNA } \\
\text { silencing }\end{array}$ & Glick et al. 2008 \\
\hline
\end{tabular}

${ }^{a}$ AGO = Argonaute, $\mathrm{DCP}=$ decapping enzyme, $\mathrm{CP}=$ coat protein, eEF1A = eukaryotic elongation factor 1- $\alpha$, RdRp = RNA-dependent RNA polymerase, $\mathrm{HCPro}=$ helper component, $\mathrm{VPg}=$ viral protein genome-linked, PTGS = posttranscriptional gene silencing, and SA = salicylic acid. 
RNA degradation, allowing viral RNA to accumulate. This nicely shows that viral proteins not only counterdefend against antiviral RNAi but may also "subvert" RNA decay to promote viral infection or RNA accumulation (Li and Wang 2018).

In addition, during TMV infection, RNA decay rates are increased while, simultaneously, the amplification of PTGS is compromised (Conti et al. 2017). Vice versa, compromising the RNA degradation activity reduces the accumulation of TMV, likely caused by aberrant viral RNAs entering PTGS. RNA decay rates have also been observed to increase upon transgenic expression of the TMV movement protein or CP. These proteins do not contain RNA silencing suppression activity, indicating that the induction of RNA decay by TMV acts as another counterdefense strategy and allows the virus to escape from an effective PTGS response. All of these studies clearly indicate the antagonistic activities of RNA decay via the RNA quality control (RQC) system and (antiviral) PTGS. RQC-degrading activities in P bodies and exosomes prevent the accumulation of aberrant mRNAs and their entering into siRNA bodies, decreasing the production of siRNAs and a lowered (antiviral) PTGS (Conti et al. 2017).
Thus far, only very few cases have been reported that have demonstrated the interaction of viral proteins with SG components. In a recent study, the nuclear shuttling proteins (NSPs) from the (nuclear replicating) geminivirus abutilon mosaic virus and nanovirus pea necrotic yellow dwarf virus were identified as potential interactors of AtG3BP1 based on the presence of a sequence with similarity to the conserved G3BP-binding motif "FGDF" in the nsP3 from alphaviruses (Krapp et al. 2017). Although both NSPs exhibited a nucleocytoplasmic distribution, upon stress induction, both colocalized and interacted with atG3BP1, likely to suppress antiviral activity of SG or to support viral replication and dissemination. Due to the presence of FGDF-like motifs, Panas et al. (2012) already suggested several potyvirus proteins to interact with G3BP as well.

Not only the P-body degradation machinery and SG are targets for virus-induced modulation or repression; also, the siRNA and miRNA pathway are modulated by viruses. Aberrant RNAs resulting from RISC cleavage of target RNAs will enter P-bodies for further degradation. As mentioned above, siRNA bodies compete with P-bodies for these aberrant RNAs,

Table 1. (Continued from previous page)

\begin{tabular}{|c|c|c|c|c|}
\hline Components & Viruses & Viral components & Function & References \\
\hline SGS3 & $\begin{array}{l}\text { Rice stripe virus } \\
\text { (RSV) }\end{array}$ & $\mathrm{p} 2$ & $\begin{array}{l}\text { Interfere with sense RNA } \\
\text { silencing, enhance PVX } \\
\text { accumulation and } \\
\text { pathogenicity }\end{array}$ & Du et al. 2011 \\
\hline RDR6 & $\begin{array}{l}\text { Rice yellow stunt } \\
\text { virus }\end{array}$ & P6 & $\begin{array}{l}\text { Inhibition of secondary } \\
\text { siRNAs production and } \\
\text { systemic RNA silencing }\end{array}$ & Guo et al. 2013 \\
\hline Nbrgs-CaM & $\begin{array}{l}\text { Tomato yellow } \\
\text { leaf curl } \\
\text { betasatellite }\end{array}$ & $\beta C 1$ & $\begin{array}{l}\text { Suppression of RDR6 gene } \\
\text { expression and PTGS }\end{array}$ & Li et al. 2014 \\
\hline \multicolumn{5}{|l|}{ Nuclear body } \\
\hline Coilin & $\begin{array}{r}\text { Tobacco rattle } \\
\text { virus (TRV) }\end{array}$ & $16 \mathrm{~K}$ & $\begin{array}{l}\text { Activation of SA-responsive } \\
\text { gene expression and } \\
\text { restriction of TRV systemic } \\
\text { infection }\end{array}$ & Shaw et al. 2019) \\
\hline Fibrillarin2 & $\begin{array}{l}\text { Grapevine red } \\
\text { blotch- } \\
\text { associated virus } \\
(\mathrm{GRBaV})\end{array}$ & $\mathrm{V} 2$ & $\begin{array}{l}\text { Movement of the viral } \\
\text { genome from the nucleus to } \\
\text { neighboring cells }\end{array}$ & Guo et al. 2015 \\
\hline Fibrillarin2 & $\begin{array}{l}\text { Barley stripe } \\
\text { mosaic virus } \\
\text { (BSMV) }\end{array}$ & TGB1 & Cell-to-cell movement & Li et al. 2018 \\
\hline Fibrillarin & $\begin{array}{l}\text { Groundnut rosette } \\
\text { virus (GRV) }\end{array}$ & ORF3 & $\begin{array}{l}\text { Formation of viral } \\
\text { ribonucleoprotein (RNP) } \\
\text { particles and long-distance } \\
\text { movement }\end{array}$ & $\begin{array}{l}\text { Canetta et al. 2008; } \\
\text { Kim et al. 2007b }\end{array}$ \\
\hline Fibrillarin & $\begin{array}{l}\text { Poa semilatent } \\
\text { virus (PSLV) }\end{array}$ & TGB1 & Unclear & Semashko et al. 2012 \\
\hline Fibrillarin & $\begin{array}{l}\text { Rice stripe } \\
\text { tenuivirus } \\
\text { (RSV) }\end{array}$ & $\mathrm{p} 2$ & $\begin{array}{l}\text { Promotion of virus systemic } \\
\text { movement }\end{array}$ & Zheng et al. 2015 \\
\hline Fibrillarin & $\begin{array}{l}\text { Bamboo mosaic } \\
\text { virus }\end{array}$ & $\mathrm{P} 20$ & $\begin{array}{l}\text { Cell-to-cell movement and } \\
\text { systemic infection }\end{array}$ & Chang et al. 2016 \\
\hline Fibrillarin & $\begin{array}{l}\text { Potato virus A } \\
\text { (PVA) }\end{array}$ & $\mathrm{VPg}$ & $\begin{array}{l}\text { Virus replication and systemic } \\
\text { movement }\end{array}$ & Rajamäki and Valkonen 2009 \\
\hline AGO4 & $\begin{array}{l}\text { Cucumber mosaic } \\
\text { virus (CMV) }\end{array}$ & $2 b$ & Suppression of RNA silencing & Fang et al. 2016 \\
\hline Importin- $\alpha$ & $\begin{array}{l}\text { Alfalfa mosaic } \\
\text { virus (AMV) }\end{array}$ & $\mathrm{CP}$ & $\begin{array}{l}\text { RNA replication and } \\
\text { movement }\end{array}$ & Herranz et al. 2012 \\
\hline Importin- $\alpha$ & $\begin{array}{l}\text { Potato mop-top } \\
\text { virus (PMTV) }\end{array}$ & TGB1 & $\begin{array}{l}\text { Virus systemic movement and } \\
\text { systematic accumulation }\end{array}$ & Lukhovitskaya et al. 2015 \\
\hline Importin & $\begin{array}{l}\text { Tombusvirus } \\
\text { Pelargonium } \\
\text { line pattern virus } \\
\text { (PLPV) }\end{array}$ & P37 & Infectivity & Pérez-Cañamás and Hernández 2018 \\
\hline ALY1-4 & $\begin{array}{l}\text { Tomato bushy } \\
\text { stunt virus } \\
\text { (TBSV) }\end{array}$ & P19 & Suppression of RNA silencing & Canto et al. 2006 \\
\hline
\end{tabular}


in which the two key elements SGS3 and RDR6 convert the aberrant RNA into dsRNA that will be processed into a population of secondary siRNAs and contribute to a stronger (antiviral) RNAi response. Viruses also target these two key elements and thereby interfere with the functionality of siRNA bodies. PVA VPg interacts with SGS3 and represses the amplification by RDR6 (Rajamäki et al. 2014). This leads to the suppression of PTGS and promotes accumulation of viral RNAs. Likewise, plantago asiatica mosaic virus TGB1, Tomato yellow leaf curl virus (TYLCV) V2, and rice stripe virus (RSV) p2 interact with SGS3, while P6 protein of rice yellow stunt virus interacts with RDR6, and inhibit the RDR6- or SGS3-mediated amplification of secondary siRNAs (Du et al. 2011; Glick et al. 2008; Guo et al. 2013; Okano et al. 2014). By interfering with the RNAi amplification in siRNA bodies, many plant viruses suppress antiviral RNAi and are able to replicate to higher levels. Cucumber mosaic virus (CMV) $2 b$ contains a GW motif that enables interaction with AGO1, thereby inhibiting the function of the PAZ and PIWI domains that are required for binding of the AGO within the RISC complex to (viral) target RNAs (Zhang et al. 2006; Zhang et al. 2017). The sweet potato mild mottle potyvirus $\mathrm{P} 1$ protein also contains a $\mathrm{WG} / \mathrm{GW}$ motif and physically interacts with AGO1 but, in contrast to CMV 2b, blocks target RNA binding to AGO1 (Kenesi et al. 2017). Plant viruses interfere not only with the RNAi amplification in siRNA bodies and RISC complex but also in other ways as well, leading to suppression of antiviral PTGS. However, it would be partly out of the scope of this article to discuss them here and readers are referred to the many other good articles and reviews that are available on this matter (Li and Wang 2019).

Plant viruses are also reported to interplay with the NMD pathway in different ways. RNA viruses often contain internal stop codons to maximize coding potential but these may also present targets for NMD. The genome of turnip crinkle virus (TCV) contains two sequence domains that confer NMD resistance. In this way, the virus is able to avoid subgenomic RNAs from being degraded and guarantee the expression of viral capsid protein (May et al. 2018). Potato virus X with internal stop codons and long $3^{\prime}$ UTRs is also prone to restriction by NMD (Garcia et al. 2014).

\section{PLANT VIRUS INTERPLAY WITH NUCLEAR GRANULES}

Considering the involvement of nuclear granules in development, disease, and stress responses (Kalinina et al. 2018; Love et al. 2017; Taliansky et al. 2010) and their role in DNA methylation and premRNA synthesis and modification, it is also not a surprise that a number of viruses target these subnuclear RNA-protein condensation centers. Considering that two host proteins that reside in nuclear granules and are important in viral infection (namely, coilin and FIB) localize to both nucleolus and CBs (Trinkle-Mulcahy and Sleeman 2017), the following section will present the state of knowledge based on virus interaction and localization rather than type of granules.

FIB is a highly conserved rRNA methyltransferase involved in prerRNA processing, and accumulates in the nucleolus, but it is also an essential scaffold protein for CBs. FIB is also essential for cell-to-cell movement, long-distance spread, and systemic infection for several plant viruses such as RSV or a satellite virus of bamboo mosaic virus (Chang et al. 2016; Zheng et al. 2015). Barley stripe mosaic virus (BSMV) and the umbravirus groundnut rosette virus hijack FIB from the nucleus to form a functional RNP, enabling them for cell-to-cell movement (Canetta et al. 2008; Kim et al. 2007a; Li et al. 2018). For several other viruses_namely, poa semilatent virus, grapevine red blotch-associated virus, and PVA-interactions with FIB have been identified but the reason for this is still not clear (Gu et al. 2015; Guo et al. 2015; Rajamäki et al. 2014; Semashko et al. 2012). The $2 \mathrm{~b}$ protein of CMV also localizes in the nucleolus ( $\mathrm{Du}$ et al. 2014). Interestingly, the $2 \mathrm{~b}$ protein shuffles between the nucleus, nucleolus, and cytoplasm; the nucleolar pool is necessary for CMV virulence and symptom development, while the cytoplasmic pool of $2 \mathrm{~b}$ controls the suppression of RNA silencing (Du et al. 2014). In the cytoplasm, 2b interacts with AGO1, whereas interactions with AGO4 occur predominantly in the nucleus but not nucleolus (González et al. 2010). Furthermore, $2 \mathrm{~b}$ binding to AGO4 is necessary for the suppression of RDR1- or RDR6-dependent antiviral silencing (Fang et al. 2016). Finally, p37 of the tombusvirus pelargonium line pattern virus (PLPV) also resides in the nucleolus together with FIB (Pérez-Cañamás and Hernández 2018). However, the nucleolar localization is not FIB dependent.

Recently, a long-noncoding RNA (lncRNA) from Arabidopsis, ELENA1, has been shown to interact with FIB2, causing FIB2 to dissociate from MED transcription complexes and leading to enhancement of immune responsive (e.g., pathogenesis-related 1) genes (Seo et al. 2019). Although not much is yet known on the role of lncRNAs on viral infections, they are known to be involved in (transcriptional) regulation of many different plant processes, including stress responses. In animal cell systems, lncRNAs have been reported as positive and negative regulators of innate antiviral responses, and their expression to be altered upon viral infection (Fortes and Morris 2016). Whether the interaction of viral proteins with FIB (as reported above) interferes with lncRNA-controlled immune responses to promote viral progression and systemic infection in plants remains to be investigated.

Proteins of the importin $\alpha$ family are important in cytoplasmnucleus trafficking (Miyamoto et al. 2016). Recently, it has been shown that three plant viruses interact with them. The tombusvirus PLPV p37 interacts with distinct members of the importin $\alpha$ family in the nucleolus and other uncharacterized subnuclear foci, and these interactions promote PLPV infectivity (Pérez-Cañamás and Hernández 2018). Potato moptop virus TGB1 protein is a part of the cell-to-cell movement protein complex. TGB1 interactions with importin $\alpha$ in the nucleus and nucleolus are essential for viral systemic movement (Lukhovitskaya et al. 2015). For AMV, the CP was shown to interact with importin (Herranz et al. 2012) and needed to support positive-strand RNA synthesis and cell-to-cell spread.

Coilin is a nuclear phosphoprotein that is an indispensable structural element of $\mathrm{CBs}$. Although the protein gene was cloned almost 30 years ago, its function remains elusive (Machyna et al. 2015). In CBs, it plays a role in snRNP biogenesis (Staněk 2017), while the nuclear pool of coilin suppresses pol I transcription during certain stress conditions (Gilder et al. 2011). Because CBs and nucleolus are functionally related, they are expected to have a role during viral infections. Indeed, plants with downregulated expression of the coilin gene showed altered responses to virus infections (Shaw et al. 2014). For some viruses such as BSMV, TRV, tomato black ring virus, and tomato golden mosaic virus, the deficiency of coilin seems to promote viral replication, whereas replication of potato virus $\mathrm{Y}$ and turnip vein-clearing virus seems to be hindered (Shaw et al. 2014). However, the exact function of coilin in viral infection remains obscure.

Although it is generally recognized that recovery from viral infections involves an RNA-silencing mediated defense response and (viral) RNA decay, recent studies indicate the additional involvement of a coilin-dependent defense mechanism (Shaw et al. 2019). Knockdown of coilin in plants or deletion of the $16 \mathrm{~K}$ silencing suppressor gene from TRV prevents systemic 
recovery. Instead, increased disease symptoms and systemic spread are observed. Coilin and TRV 16K physically interact, indicating a concerted action to induce a defense response that leads to recovery. This is supported by the observation that the interaction with $16 \mathrm{~K}$ leads to a nucleolar relocalization of coilin in fully infected (older) leaves and occurs relatively early during the infection cycle (i.e., prior to full development of upper leaves) (Shaw et al. 2019). During this process, salicylic acid (SA) levels are increased and suggest an important role, although coilin relocalization occurs independent of SA.

ALY proteins were recently described to have a role in RNA export from the nucleus to the cytoplasm. In Arabidopsis, four ALY proteins have been identified thus far (Pfaff et al. 2018). ALY1 and ALY2 proteins often are localized to speckles and foci within the nucleoplasm, while ALY3 and ALY4 were also found in the nucleolus (Pfaff et al. 2018; L. Wang et al. 2017). Interestingly, evidence is accumulating that they are important players during viral infections. During TYLCV infection, ALY4 translocates from the nucleolus to further uncharacterized NSs (L. Wang et al. 2017). Importantly, transiently expressed CP of TYLCV localizes with ALY4 in the nucleolus but no interactions between ALY and viral proteins have been described (L. Wang et al. 2017). P19 protein of TBSV is an RNA silencing suppressor but its presence is also required for short- and long-distance virus movement and symptom development. P19 interacts with Arabidopsis ALY2 to -4 proteins in the nucleus and with ALY1 in the nucleolus (Canto et al. 2006). The interactions lead to translocation of ALY2 and ALY4 from the nucleus to the cytoplasm (Uhrig et al. 2004). Although ALY1 does not relocate in the presence of P19, it hinders P19 in suppressing RNA silencing (Canto et al. 2006). Interestingly, mutant plants lacking ALY1 are hindered in RdDM caused by mRNA trafficking of AGO6 and the activities of RNA Pol V (Choudury et al. 2019), both crucial for silencing of geminiviruses during the recovery phase of infection (Coursey et al. 2018).

\section{CONCLUSIONS AND OUTLOOK}

Although the role of cytoplasmic and nuclear RNA granules as a hub in the regulation of cellular processes, homeostasis, and biotic or abiotic stress responses is clearly recognized, ongoing studies keep unveiling more details that indicate their complexity, interplay, and involvement in more processes than initially thought of. Studies on viruses simultaneously turn out to present helpful tools in this investigation. Although, in the past decade, this field of science has made more progress with animal-infecting viruses, due to the conservation of many RNA regulation processes in eukaryotes, knowledge obtained with animal-infecting viruses can be taken as interesting leads for studies with plant viruses. Plant cells and animal cells, however, do exhibit differences in their cellular architecture and organization, as is well exemplified by (i) the presence of siRNA bodies, for the amplification of RNAi, in plant cells and their absence from animal cells; (ii) the absence of GW-182 bodies from plant cells and their presence in animal cells; and (iii) seeming differences in the cellular localization of siRNA- or miRNA-mediated RNA silencing in plant versus animal cells. On the other hand, with ongoing studies revealing the existence of P-body-like bodies (GW-182), SG-like bodies, and CB-like bodies, indicating a growing complexity of RNA granules and their transiently different status, the regulation of various processes in plant and animal cells, in the end, might turn out to be not so much different at all. This idea is supported by the observation that plant proteins have been identified with functional or structural similarities to certain animal proteins (e.g., plant host proteins containing GW motifs and exhibiting a functional similarity to the animal GW-182 protein, or the plant
COP1 protein with functional or structural similarity to the nuclear PML protein of animal cells) (Reyes 2001).

Although we are just at the start of an era where studies of plant viruses and the interplay with RNA granules receive growing attention, studies that are reported on this topic often have remained elusive as to the how and why of the interplay in relation to the benefit for viral replication and dissemination or counterdefense strategies against antiviral responses. On the other hand, details of the molecular biology and genetics of viruses may also point to issues relevant for the mechanism of RNA regulation and dynamics related to RNA granules. Viruses that could be of special interest and support to these studies are families containing plantand animal-infecting viruses (e.g., rhabdoviruses and bunyaviruses). The structural and functional homologies between the genomes and proteins of the plant- and animal-infecting counterparts, while having to cope with the host cell machinery that seems to differ in architecture and organization (plant versus animal), turn research on the interplay between those viruses and RNA granules into a very interesting challenge.

Let's look at a few examples. In the past few years, studies in animal cells have revealed a cellular mechanism that acts antivirally and represses $\mathrm{CpG} / \mathrm{UpA}$ dinucleotides in animal RNA viruses (Fros et al. 2017). This repression does not involve a changed phosphorylation status of eIF $2 \alpha$ (SG inducer). Instead, a zinc-finger antiviral protein (ZAP) has been shown to be involved in the selective binding to $\mathrm{CpG}$ sequences, and viruses high in $\mathrm{CpG}$ contents are only able to replicate to wild-type virus levels in ZAP knock-out cells (Takata et al. 2017). A recent study showed that ZAP can be found in the cytoplasm but transiently localizes to SG during (Sindbis) virus replication. The antiviral activity correlated with the ability to localize in SG support the idea of SG presenting an important hub in antiviral defense (Law et al. 2019). Furthermore, in another study, the enterovirus A71 3C protease has been shown to cleave ZAP (Xie et al. 2018), clearly as a means to (partly) escape from this (antiviral) host response. Considering that plant genomes also exhibit $\mathrm{CpG}$ repression, it will be interesting to find out whether a similar mechanism exists in plants that represses $\mathrm{CpG}(/ \mathrm{UpA})$ dinucleotides and also acts on plant viral RNA genomes.

Another interesting question relates to viruses that rely on or benefit from P-bodies for genome transcription or replication (e.g., bromoviruses and bunyaviruses). Localizing at P-bodies makes their genomic (m)RNA vulnerable and prone to degradation by the decay machinery. However, bromoviruses do not contain a poly(A)-tail but, instead, a $3^{\prime}$ UTR that folds in a tRNA-like structure and is not prone to deadenylation. Maybe it is for this reason that bromoviral RNAs, localizing at P-bodies (Beckham et al. 2007), resist degradation and are able to replicate. A similar question pops up with bunyaviruses, where several studies on SNV have shown a link to P-bodies as sites of viral genome transcription (Mir et al. 2008). Viral mRNAs of hantaviruses, as with all bunyaviruses, do not contain a common eukaryotic poly(A)-tail. If hantaviruses or bunyaviruses localize at P-bodies, from which these viruses would collect host-capped RNA leader sequences for genome transcription initiation, it would seem logical to assume that these viruses have evolved strategies to protect or take their nonpolyadenaylated viral mRNAs away from P-bodies to prevent degradation by the RNA decay machinery. Whether this involves a similar (sequence-dependent) strategy as observed with TCV (May et al. 2018), where the viral genome contains NMD-resistant sequences to prevent degradation of viral RNA at P-bodies, remains to be investigated. In light of this, it is also interesting to note that a recent study has shown that the polypyrimidine tract-binding protein 1 (PTBP1) protects specific retroviral and host cellular mRNAs with long $3^{\prime}$ UTR sequences from the NMD pathway. Binding of PTBP1 in the $3^{\prime}$ UTRs on 
pyrimidine-rich stretches near TCs prevents binding of UPF1, a protein that, once bound, disposes (even functional) transcripts to the NMD pathway (Ge et al. 2016). Bunyaviral mRNAs do not contain a common eukaryotic poly(A)-tail but some members, instead, contain a long $3^{\prime}$ UTR that is predicted to fold into a stable hairpin structure (Kormelink 2011). Furthermore, some bunyavirus mRNAs contain just downstream the $\mathrm{TC}$ stretches rich in $\mathrm{C}$ and $U$ residues. Intriguingly, tomato spotted wilt virus (TSWV) mRNAs also contain sequence signatures within their 3'UTR that resemble ARE (AUUUA) elements, which are known to destabilize mRNAs (Geerts-Dimitriadou et al. 2012). Whether these are biologically functional and, via RNA-binding proteins, target TSWV mRNAs to P-bodies for degradation remains to be investigated. In retrospect, and in light of the intimacy between Pbodies and SGs, in which many RNA molecules and proteins are exchanged, one might also question whether or not hantaviruses or bunyaviruses use SG as a source for capped RNA leaders as well (Mir et al. 2008); in addition, U-bodies could present a source. Ubodies were discovered not long ago and present RNP structures that contain uridine-rich, capped small nuclear (sn)RNAs that mature in the cytoplasm and also associate with P-bodies (Liu and Gall 2007) but finally localize in the nucleus, where they play a key role in (RNA Pol II complex-mediated) premRNA processing. Support for U-bodies as being another source comes from two recent studies on influenza virus transcription, where snRNAs presented a preferred source for capped-RNA leaders $(\mathrm{Gu}$ et al. 2015; Koppstein et al. 2015).

Although, at this moment, many questions remain about the cellular RNA communication network, finding the answer to these will not only advance our understanding and the importance of RNA sequence elements and host proteins in this but also help us to understand how viruses have evolved to modulate and benefit from the RNA communication network and simultaneously repress or evade network activities that would otherwise inhibit viral replication and dissemination. In relation to this, a recent systemwide profiling of the RBP network has unveiled unknown key regulators of virus infection (Garcia-Moreno et al. 2019). In a study on sindbis virus (SINV) infection of animal cells, more than 200 RBPs were observed to alter their binding profile, due to the loss of host mRNA and accumulation of viral RNA. RBPs were observed to redistribute to viral factories, likely to enable viral infection but also as a means of the host to defend against viral invasion. Although the exonuclease XRN1 is generally assumed to present an antiviral factor, this protein appeared essential for SINV replication. Gemin5, a protein of the SMN complex, required for snRNP assembly, appeared to colocalize with SINV RNA in viral factories and, by binding to the 5'-Cap, inhibited translation by interference with ribosomes (Garcia-Moreno et al. 2019).

The interplay of viruses with the cellular RNA communication network is of vital importance. If viruses want to maximally exploit the host cell machinery, they also have to avoid being sensed by RNA surveillance and control mechanisms of the host, aimed at homeostasis. The latter is not directed at and necessary for viral clearance per se but at RNA control and regulation, to which viral (m)RNA will be subjected as well.

\section{LITERATURE CITED}

Anderson, P., and Kedersha, N. 2008. Stress granules: The Tao of RNA triage. Trends Biochem. Sci. 33:141-150.

Anderson, P., and Kedersha, N. 2009. RNA granules: Post-transcriptional and epigenetic modulators of gene expression. Nat. Rev. Mol. Cell Biol. $10: 430-436$

Azevedo, J., Garcia, D., Pontier, D., Ohnesorge, S., Yu, A., Garcia, S., Braun, L., Bergdoll, M., Hakimi, M. A., Lagrange, T., and Voinnet, O. 2010. Argonaute quenching and global changes in Dicer homeostasis caused by a pathogen-encoded GW repeat protein. Genes Dev. 24: 904-915.
Baumberger, N., Tsai, C. H., Lie, M., Havecker, E., and Baulcombe, D. C. 2007. The Polerovirus silencing suppressor P0 targets ARGONAUTE proteins for degradation. Curr. Biol. 17:1609-1614.

Beauchemin, C., Boutet, N., and Laliberté, J. F. 2006. Visualization of the interaction between the precursors of VPg, the viral protein linked to the genome of turnip mosaic virus, and the translation eukaryotic initiation factor iso 4E in Planta. J. Virol. 81:775-782.

Beauchemin, C., and Laliberté, J. F. 2007. The poly(A) binding protein is internalized in virus-induced vesicles or redistributed to the nucleolus during turnip mosaic virus infection. J. Virol. 81:10905-10913.

Beckham, C. J., Light, H. R., Nissan, T. A., Ahlquist, P., Parker, R., and Noueiry, A. 2007. Interactions between brome mosaic virus RNAs and cytoplasmic processing bodies. J. Virol. 81:9759-9768.

Beckham, C. J., and Parker, R. 2008. P bodies, stress granules, and viral life cycles. Cell Host Microbe 3:206-212.

Behm-Ansmant, I., Rehwinkel, J., Doerks, T., Stark, A., Bork, P., and Izaurralde, E. 2006. mRNA degradation by miRNAs and GW182 requires both CCR4:NOT deadenylase and DCP1:DCP2 decapping complexes. Genes Dev. 20:1885-1898.

Bhasin, H., and Hülskamp, M. 2017. ANGUSTIFOLIA, a plant homolog of $\mathrm{CtBP} / \mathrm{BARS}$ localizes to stress granules and regulates their formation. Front. Plant Sci. 8:1004.

Bhullar, D. S., Sheahan, M. B., and Rose, R. J. 2017. RNA processing body (P-body) dynamics in mesophyll protoplasts re-initiating cell division. Protoplasma 254:1627-1637.

Bies-Etheve, N., Pontier, D., Lahmy, S., Picart, C., Vega, D., Cooke, R., and Lagrange, T. 2009. RNA-directed DNA methylation requires an AGO4interacting member of the SPT5 elongation factor family. EMBO Rep. 10:649-654.

Bond, C. S., and Fox, A. H. 2009. Paraspeckles: Nuclear bodies built on long noncoding RNA. J. Cell Biol. 186:637-644.

Bortolamiol, D., Pazhouhandeh, M., Marrocco, K., Genschik, P., and Ziegler-Graff, V. 2007. The Polerovirus F box protein P0 targets ARGONAUTE1 to suppress RNA silencing. Curr. Biol. 17: 1615-1621.

Boudonck, K., Dolan, L., and Shaw, P. J. 1998. Coiled body numbers in the Arabidopsis root epidermis are regulated by cell type, developmental stage and cell cycle parameters. J. Cell Sci. 111:3687-3694.

Boudonck, K., Dolan, L., and Shaw, P. J. 1999. The movement of coiled bodies visualized in living plant cells by the green fluorescent protein. Mol. Biol. Cell 10:2297-2307.

Boulon, S., Westman, B. J., Hutten, S., Boisvert, F. M., and Lamond, A. I. 2010. The nucleolus under stress. Mol. Cell 40:216-227.

Braun, J. E., Huntzinger, E., and Izaurralde, E. 2013. The role of GW182 proteins in miRNA-mediated gene silencing. Pages 147-163 in: Ten Years of Progress in GW/P Body Research. Advances in Experimental Medicine and Biology, Vol. 768. E. Chan and M. Fritzler, eds. Springer, New York, NY, U.S.A.

Brengues, M., and Parker, R. 2007. Accumulation of polyadenylated mRNA, Pab1p, eIF4E, and eIF4G with P-bodies in Saccharomyces cerevisiae. Mol. Biol. Cell 18:2592-2602.

Brengues, M., Teixeira, D., and Parker, R. 2005. Movement of eukaryotic mRNAs between polysomes and cytoplasmic processing bodies. Science 310:486-489.

Butterbach, P., Verlaan, M. G., Dullemans, A., Lohuis, D., Visser, R. G., Bai, Y., and Kormelink, R. 2014. Tomato yellow leaf curl virus resistance by Ty-1 involves increased cytosine methylation of viral genomes and is compromised by Cucumber mosaic virus infection. Proc. Natl. Acad. Sci. U.S.A. 111:12942-12947.

Canetta, E., Kim, S. H., Kalinina, N. O., Shaw, J., Adya, A. K., Gillespie, T., Brown, J. W., and Taliansky, M. 2008. A plant virus movement protein forms ringlike complexes with the major nucleolar protein, fibrillarin, in vitro. J. Mol. Biol. 376:932-937.

Canto, T., Uhrig, J. F., Swanson, M., Wright, K. M., and MacFarlane, S. A. 2006. Translocation of Tomato bushy stunt virus P19 protein into the nucleus by ALY proteins compromises its silencing suppressor activity. J. Virol. 80:9064-9072.

Chang, C. H., Hsu, F. C., Lee, S. C., Lo, Y. S., Wang, J. D., Shaw, J., Taliansky, M., Chang, B. Y., Hsu, Y. H., and Lin, N. S. 2016. The nucleolar fibrillarin protein is required for helper virus-independent long-distance trafficking of a subviral satellite RNA in plants. Plant Cell 28:2586-2602.

Chekulaeva, M., Mathys, H., Zipprich, J. T., Attig, J., Colic, M., Parker, R., and Filipowicz, W. 2011. miRNA repression involves GW182-mediated recruitment of CCR4-NOT through conserved W-containing motifs. Nat. Struct. Mol. Biol. 18:1218-1226.

Cheng, C. P., Jaag, H. M., Jonczyk, M., Serviene, E., and Nagy, P. D. 2007. Expression of the Arabidopsis Xrn4p 5'-3' exoribonuclease facilitates 
degradation of tombusvirus RNA and promotes rapid emergence of viral variants in plants. Virology 368:238-248.

Chicois, C., Scheer, H., Garcia, S., Zuber, H., Mutterer, J., Chicher, J., Hammann, P., Gagliardi, D., and Garcia, D. 2018. The UPF1 interactome reveals interaction networks between RNA degradation and translation repression factors in Arabidopsis. Plant J. 96:119-132.

Chiu, M. H., Chen, I. H., Baulcombe, D. C., and Tsai, C. H. 2010. The silencing suppressor P25 of Potato virus $X$ interacts with Argonaute1 and mediates its degradation through the proteasome pathway. Mol. Plant Pathol. 11:641-649.

Choudury, S. G., Shahid, S., Cuerda-Gil, D., Panda, K., Cullen, A., Ashraf, Q., Sigman, M. J., McCue, A. D., and Slotkin, R. K. 2019. The RNA export factor ALY1 enables genome-wide RNA-directed DNA methylation. Plant Cell 31:759-774.

Coller, J., and Parker, R. 2005. General translational repression by activators of mRNA decapping. Cell 122:875-886.

Collier, S., Pendle, A., Boudonck, K., van Rij, T., Dolan, L., and Shaw, P. 2006. A distant coilin homologue is required for the formation of Cajal bodies in Arabidopsis. Mol. Biol. Cell 17:2942-2951.

Conti, G., Zavallo, D., Venturuzzi, A. L., Rodriguez, M. C., Crespi, M., and Asurmendi, S. 2017. TMV induces RNA decay pathways to modulate gene silencing and disease symptoms. Plant J. 89:73-84.

Coursey, T., Regedanz, E., and Bisaro, D. M. 2018. Arabidopsis RNA polymerase $\mathrm{V}$ mediates enhanced compaction and silencing of geminivirus and transposon chromatin during host recovery from infection. J. Virol. 92:e01320-17.

del Olmo, I., López, J. A., Vázquez, J., Raynaud, C., Piñeiro, M., and Jarillo, J. A. 2016. Arabidopsis DNA polymerase $€$ recruits components of Polycomb repressor complex to mediate epigenetic gene silencing. Nucleic Acids Res. 44:5597-5614.

Dinh, P. X., Das, A., Franco, R., and Pattnaik, A. K. 2013. Heterogeneous nuclear ribonucleoprotein $\mathrm{K}$ supports vesicular stomatitis virus replication by regulating cell survival and cellular gene expression. J. Virol. 87: 10059-10069.

Dong, O. X., Meteignier, L. V., Plourde, M. B., Ahmed, B., Wang, M., Jensen, C., Jin, H., Moffett, P., Li, X., and Germain, H. 2016. Arabidopsis TAF15b localizes to RNA processing bodies and contributes to sncl-mediated autoimmunity. Mol. Plant-Microbe Interact. 29:247-257.

Du, Z., Chen, A., Chen, W., Liao, Q., Zhang, H., Bao, Y., Roossinck, M. J., and Carr, J. P. 2014. Nuclear-cytoplasmic partitioning of Cucumber mosaic virus protein $2 \mathrm{~b}$ determines the balance between its roles as a virulence determinant and an RNA-silencing suppressor. J. Virol. 88: 5228-5241.

Du, Z., Xiao, D., Wu, J., Jia, D., Yuan, Z., Liu, Y., Hu, L., Han, Z., Wei, T. Lin, Q., Wu, Z., and Xie, L. 2011. p2 of Rice stripe virus (RSV) interacts with OsSGS3 and is a silencing suppressor. Mol. Plant Pathol. 12: 808-814.

Dubois, M.-L., and Boisvert, F.-M. 2016. The Nucleolus: Structure and Function. Springer International Publishing Ag, Cham, Switzerland.

Dundr, M., and Misteli, T. 2010. Biogenesis of nuclear bodies. Cold Spring Harb. Perspect. Biol. 2:a000711.

Eulalio, A., Behm-Ansmant, I., and Izaurralde, E. 2007. P bodies: At the crossroads of post-transcriptional pathways. Nat. Rev. Mol. Cell Biol. 8: 9-22.

Eulalio, A., Huntzinger, E., and Izaurralde, E. 2008. Getting to the root of miRNA-mediated gene silencing. Cell 132:9-14.

Eulalio, A., Huntzinger, E., Nishihara, T., Rehwinkel, J., Fauser, M., and Izaurralde, E. 2009. Deadenylation is a widespread effect of miRNA regulation. RNA 15:21-32.

Eystathioy, T., Chan, E. K., Tenenbaum, S. A., Keene, J. D., Griffith, K., and Fritzler, M. J. 2002. A phosphorylated cytoplasmic autoantigen, GW182, associates with a unique population of human mRNAs within novel cytoplasmic speckles. Mol. Biol. Cell 13:1338-1351.

Eystathioy, T., Jakymiw, A., Chan, E. K. L., Séraphin, B., Cougot, N., and Fritzler, M. J. 2003. The GW182 protein colocalizes with mRNA degradation associated proteins hDcpl and hLSm4 in cytoplasmic GW bodies. RNA 9:1171-1173.

Fang, Y., and Spector, D. L. 2007. Identification of nuclear dicing bodies containing proteins for microRNA biogenesis in living Arabidopsis plants. Curr. Biol. 17:818-823.

Fang, Y. Y., Zhao, J. H., Liu, S. W., Wang, S., Duan, C. G., and Guo, H. S 2016. CMV2b-AGO interaction is required for the suppression of RDRdependent antiviral silencing in Arabidopsis. Front. Microbiol. 7:1329.

Feng, Q., Jagannathan, S., and Bradley, R. K. 2017. The RNA surveillance factor UPF1 represses myogenesis via its E3 ubiquitin ligase activity. Mol. Cell 67:239-251.e6

Fontaine, K. A., Leon, K. E., Khalid, M. M., Tomar, S., Jimenez-Morales, D., Dunlap, M., Kaye, J. A., Shah, P. S., Finkbeiner, S., Krogan, N. J., and Ott, M. 2018. The cellular NMD pathway restricts zika virus infection and is targeted by the viral capsid protein. MBio 9:e02126-18

Fortes, P., and Morris, K. V. 2016. Long noncoding RNAs in viral infections. Virus Res. 212:1-11.

Fox, A. H., Nakagawa, S., Hirose, T., and Bond, C. S. 2018. Paraspeckles Where long noncoding RNA meets phase separation. Trends Biochem. Sci. 43:124-135.

Freire, M. A. 2014. Potyviral VPg and HC-Pro proteins and the cellular translation initiation factor eIF(iso)4E interact with exoribonuclease Rrp6 and a small $\alpha$-heat shock protein. Plant Mol. Biol. Rep. 32:596-604.

Fros, J. J., Dietrich, I., Alshaikhahmed, K., Passchier, T. C., Evans, D. J., and Simmonds, P. 2017. CpG and UpA dinucleotides in both coding and non-coding regions of echovirus 7 inhibit replication initiation postentry. eLife 6:e29112.

Fros, J. J., Domeradzka, N. E., Baggen, J., Geertsema, C., Flipse, J., Vlak, J. M., and Pijlman, G. P. 2012. Chikungunya virus nsP3 blocks stress granule assembly by recruitment of G3BP into cytoplasmic foci. J. Virol. 86:10873-10879.

Fujioka, Y., Utsumi, M., Ohba, Y., and Watanabe, Y. 2007. Location of a possible miRNA processing site in $\mathrm{SmD} 3 / \mathrm{SmB}$ nuclear bodies in Arabidopsis. Plant Cell Physiol. 48:1243-1253.

Fukuhara, N., Ebert, J., Unterholzner, L., Lindner, D., Izaurralde, E., and Conti, E. 2005. SMG7 is a 14-3-3-like adaptor in the nonsense-mediated mRNA decay pathway. Mol. Cell 17:537-547.

Galganski, L., Urbanek, M. O., and Krzyzosiak, W. J. 2017. Nuclear speckles: Molecular organization, biological function and role in disease. Nucleic Acids Res. 45:10350-10368.

Garaigorta, U., Heim, M. H., Boyd, B., Wieland, S., and Chisari, F. V. 2012. Hepatitis $\mathrm{C}$ virus (HCV) induces formation of stress granules whose proteins regulate HCV RNA replication and virus assembly and egress. J. Virol. 86:11043-11056.

Garcia, D., Garcia, S., Pontier, D., Marchais, A., Renou, J. P., Lagrange, T., and Voinet, O. 2012. Ago hook and RNA helicase motifs underpin dual roles for SDE3 in antiviral defense and silencing of nonconserved intergenic regions. Mol. Cell 48:109-120.

Garcia, D., Garcia, S., and Voinnet, O. 2014. Nonsense-mediated decay serves as a general viral restriction mechanism in plants. Cell Hos Microbe 16:391-402.

Garcia-Moreno, M., Noerenberg, M., Ni, S., Järvelin, A. I., González-Almela, E., Lenz, C. E., Bach-Pages, M., Cox, V., Avolio, R., Davis, T., Hester, S., Sohier, T. J. M., Li, B., Heikel, G., Michlewski, G., Sanz, M. A., Carrasco, L., Ricci, E. P., Pelechano, V., Davis, I., Fischer, B., Mohammed, S., and Castello, A. 2019. System-wide profiling of RNA-binding proteins uncovers key regulators of virus infection. Mol. Cell 74:196-211.e11.

Ge, Z., Quek, B. L., Beemon, K. L., and Hogg, J. R. 2016. Polypyrimidine tract binding protein 1 protects mRNAs from recognition by the nonsense-mediated mRNA decay pathway. eLife 5:e11155.

Geerts-Dimitriadou, C., Lu, Y. Y., Geertsema, C., Goldbach, R., and Kormelink, R. 2012. Analysis of the Tomato spotted wilt virus ambisense S RNA-encoded hairpin structure in translation. PLoS One 7:e31013.

Ghoshal, B., and Sanfaçon, H. 2014. Temperature-dependent symptom recovery in Nicotiana benthamiana plants infected with tomato ringspot virus is associated with reduced translation of viral RNA2 and requires ARGONAUTE 1. Virology 456-457:188-197.

Gilder, A. S., Do, P. M., Carrero, Z. I., Cosman, A. M., Broome, H. J., Velma, V., Martinez, L. A., and Hebert, M. D. 2011. Coilin participates in the suppression of RNA polymerase I in response to cisplatin-induced DNA damage. Mol. Biol. Cell 22:1070-1079.

Glick, E., Zrachya, A., Levy, Y., Mett, A., Gidoni, D., Belausov, E., Citovsky, V., and Gafni, Y. 2008. Interaction with host SGS3 is required for suppression of RNA silencing by tomato yellow leaf curl virus V2 protein. Proc. Natl. Acad. Sci. U.S.A. 105:157-161.

González, I., Martínez, L., Rakitina, D. V., Lewsey, M. G., Atencio, F. A., Llave, C., Kalinina, N. O., Carr, J. P., Palukaitis, P., and Canto, T. 2010. Cucumber mosaic virus $2 \mathrm{~b}$ protein subcellular targets and interactions: Their significance to RNA silencing suppressor activity. Mol. PlantMicrobe Interact.23:294-303.

Gu, W., Gallagher, G. R., Dai, W., Liu, P., Li, R., Trombly, M. I., Gammon, D. B., Mello, C. C., Wang, J. P., and Finberg, R. W. 2015. Influenza A virus preferentially snatches noncoding RNA caps. RNA 21:2067-2075.

Guo, H., Song, X., Xie, C., Huo, Y., Zhang, F., Chen, X., Geng, Y., and Fang, R. 2013. Rice yellow stunt rhabdovirus protein 6 suppresses systemic RNA silencing by blocking RDR6-mediated secondary siRNA synthesis. Mol. Plant-Microbe Interact. 26:927-936.

Guo, T. W., Vimalesvaran, D., Thompson, J. R., Perry, K. L., and Krenz, B. 2015. Subcellular localization of grapevine red blotch-associated virus ORFs V2 and V3. Virus Genes 51:156-158. 
Gutierrez-Beltran, E., Moschou, P. N., Smertenko, A. P., and Bozhkov, P. V. 2015. Tudor staphylococcal nuclease links formation of stress granules and processing bodies with mRNA catabolism in Arabidopsis. Plant Cell 27:926-943.

Hafrén, A., Eskelin, K., and Mäkinen, K. 2013. Ribosomal protein P0 promotes Potato virus $A$ infection and functions in viral translation together with VPg and eIF(iso)4E. J. Virol. 87:4302-4312.

Hafrén, A., Lõhmus, A., and Mäkinen, K. 2015. Formation of Potato virus $A$-induced RNA granules and viral translation are interrelated processes required for optimal virus accumulation. PLoS Pathog. 11:e1005314.

Hannon, G. J. 2002. RNA interference. Nature 418:244-251.

Hebner, C. M., and Laimins, L. A. 2006. Human papillomaviruses: Basic mechanisms of pathogenesis and oncogenicity. Rev. Med. Virol. 16: 83-97.

Herranz, M. C., Pallas, V., and Aparicio, F. 2012. Multifunctional roles for the N-terminal basic motif of Alfalfa mosaic virus coat protein: Nucleolar/cytoplasmic shuttling, modulation of RNA-binding activity, and virion formation. Mol. Plant-Microbe Interact. 25:1093-1103.

Höfer, C. T., Jolmes, F., Haralampiev, I., Veit, M., and Herrmann, A. 2017. Influenza A virus nucleoprotein targets subnuclear structures. Cell Microbiol. 19:e12679.

Ingelfinger, D., Arndt-Jovin, D. J., Lührmann, R., and Achsel, T. 2002. The human LSm1-7 proteins colocalize with the mRNA-degrading enzymes Dcp1/2 and Xrnl in distinct cytoplasmic foci. RNA 8:1489-1501.

Jaag, H. M., and Nagy, P. D. 2009. Silencing of Nicotiana benthamiana Xrn4p exoribonuclease promotes tombusvirus RNA accumulation and recombination. Virology 386:344-352.

Jakymiw, A., Lian, S., Eystathioy, T., Li, S., Satoh, M., Hamel, J. C., Fritzler, M. J., and Chan, E. K. L. 2005. Disruption of GW bodies impairs mammalian RNA interference. Nat. Cell Biol. 7:1267-1274.

Kalinina, N. O., Makarova, S., Makhotenko, A., Love, A. J., and Taliansky, M. 2018. The multiple functions of the nucleolus in plant development, disease and stress responses. Front. Plant Sci. 9:132.

Karran, R. A., and Sanfaçon, H. 2014. Tomato ringspot virus coat protein binds to ARGONAUTE 1 and suppresses the translation repression of a reporter gene. Mol. Plant-Microbe Interact. 27:933-943.

Kedersha, N., Stoecklin, G., Ayodele, M., Yacono, P., Lykke-Andersen, J., Fritzler, M. J., Scheuner, D., Kaufman, R. J., Golan, D. E., and Anderson, P. 2005. Stress granules and processing bodies are dynamically linked sites of mRNP remodeling. J. Cell Biol. 169:871-884.

Kedersha, N. L., Gupta, M., Li, W., Miller, I., and Anderson, P. 1999 RNA-binding proteins TIA-1 and TIAR link the phosphorylation of eIF- $2 \alpha$ to the assembly of mammalian stress granules. J. Cell Biol. 147:1431-1442.

Kenesi, E., Carbonell, A., Lózsa, R., Vértessy, B., and Lakatos, L. 2017. A viral suppressor of RNA silencing inhibits ARGONAUTE 1 function by precluding target RNA binding to pre-assembled RISC. Nucleic Acids Res. 45:7736-7750.

Khaperskyy, D. A., Hatchette, T. F., and McCormick, C. 2012. Influenza A virus inhibits cytoplasmic stress granule formation. FASEB J. 26: 1629-1639.

Kim, S. H., Macfarlane, S., Kalinina, N. O., Rakitina, D. V., Ryabov, E. V., Gillespie, T., Haupt, S., Brown, J. W., and Taliansky, M. 2007a. Interaction of a plant virus-encoded protein with the major nucleolar protein fibrillarin is required for systemic virus infection. Proc. Natl. Acad. Sci. U.S.A. 104:11115-11120.

Kim, S. H., Ryabov, E. V., Brown, J. W., and Taliansky, M. 2004 Involvement of the nucleolus in plant virus systemic infection. Biochem. Soc. Trans. 32:557-560.

Kim, S. H., Ryabov, E. V., Kalinina, N. O., Rakitina, D. V., Gillespie, T., MacFarlane, S., Haupt, S., Brown, J. W., and Taliansky, M. 2007b. Cajal bodies and the nucleolus are required for a plant virus systemic infection. EMBO J. 26:2169-2179.

Kim, Y. K., and Maquat, L. E. 2019. UPFront and center in RNA decay: UPF1 in nonsense-mediated mRNA decay and beyond. RNA 25: 407-422.

Koppstein, D., Ashour, J., and Bartel, D. P. 2015. Sequencing the cap-snatching repertoire of $\mathrm{H} 1 \mathrm{~N} 1$ influenza provides insight into the mechanism of viral transcription initiation. Nucleic Acids Res. 43:5052-5064.

Kormelink, R., Garcia, M. L., Goodin, M., Sasaya, T., and Haenni, A.-L. 2011. Negative-strand RNA viruses: The plant-infecting counterparts. Virus Res. 162:184-202.

Krapp, S., Greiner, E., Amin, B., Sonnewald, U., and Krenz, B. 2017. The stress granule component G3BP is a novel interaction partner for the nuclear shuttle proteins of the nanovirus pea necrotic yellow dwarf virus and geminivirus abutilon mosaic virus. Virus Res. 227:6-14.

Kulkarni, M., Ozgur, S., and Stoecklin, G. 2010. On track with P-bodies. Biochem. Soc. Trans. 38:242-251.
Kumakura, N., Takeda, A., Fujioka, Y., Motose, H., Takano, R., and Watanabe, Y. 2009. SGS3 and RDR6 interact and colocalize in cytoplasmic SGS3/RDR6-bodies. FEBS Lett. 583:1261-1266.

Kurihara, Y., Takashi, Y., and Watanabe, Y. 2006. The interaction between DCL1 and HYL1 is important for efficient and precise processing of primiRNA in plant microRNA biogenesis. RNA 12:206-212.

Lahmy, S., Pontier, D., Cavel, E., Vega, D., El-Shami, M., Kanno, T., and Lagrange, T. 2009. PolV(PolIVb) function in RNA-directed DNA methylation requires the conserved active site and an additional plantspecific subunit. Proc. Natl. Acad. Sci. U.S.A. 106:941-946.

Law, L. M. J., Razooky, B. S., Li, M. M. H., You, S., Jurado, A., Rice, C. M., and MacDonald, M. R. 2019. ZAP's stress granule localization is correlated with its antiviral activity and induced by virus replication. PLoS Pathog. 15:e1007798.

Li, C. F., Pontes, O., El-Shami, M., Henderson, I. R., Bernatavichute, Y. V., Chan, S. W. L., Lagrange, T., Pikaard, C. S., and Jacobsen, S. E. 2006. An ARGONAUTE4-containing nuclear processing center colocalized with Cajal bodies in Arabidopsis thaliana. Cell 126: 93-106.

Li, F., Huang, C., Li, Z., and Zhou, X. 2014. Suppression of RNA silencing by a plant DNA virus satellite requires a host calmodulin-like protein to repress RDR6 expression. PLoS Pathog. 10:e1003921.

Li, F., and Wang, A. 2018. RNA decay is an antiviral defense in plants that is counteracted by viral RNA silencing suppressors. PLoS Pathog. 14: e1007228.

Li, F., and Wang, A. 2019. RNA-targeted antiviral immunity: More than just RNA silencing. Trends Microbiol. 27:792-805.

Li, J., Hu, S., Xu, F., Mei, S., Liu, X., Yin, L., Zhao, F., Zhao, X., Sun, H., Xiong, Z., Zhang, D., Cen, S., Wang, J., Liang, C., and Guo, F. 2019. MOV10 sequesters the RNP of influenza A virus in the cytoplasm and is antagonized by viral NS1 protein. Biochem. J. 476:467-481.

Li, M., Johnson, J. R., Truong, B., Kim, G., Weinbren, N., Dittmar, M., Shah, P. S., Von Dollen, J., Newton, B. W., Jang, G. M., Krogan, N. J., Cherry, S., and Ramage, H. 2019. Identification of antiviral roles for the exon-junction complex and nonsense-mediated decay in flaviviral infection. Nat. Microbiol. 4:985-995.

Li, W., Li, Y., Kedersha, N., Anderson, P., Emara, M., Swiderek, K. M., Moreno, G. T., and Brinton, M. A. 2002. Cell proteins TIA-1 and TIAR interact with the $3^{\prime}$ stem-loop of the West Nile virus complementary minus-strand RNA and facilitate virus replication. J. Virol. 76: 11989-12000.

Li, Y. R., King, O. D., Shorter, J., and Gitler, A. D. 2013. Stress granules as crucibles of ALS pathogenesis. J. Cell. Biol. 201:361-372.

Li, Z., Zhang, Y., Jiang, Z., Jin, X., Zhang, K., Wang, X., Han, C., Yu, J., and Li, D. 2018. Hijacking of the nucleolar protein fibrillarin by TGB1 is required for cell-to-cell movement of Barley stripe mosaic virus. Mol. Plant Pathol. 19:1222-1237.

Lingel, A., and Sattler, M. 2005. Novel modes of protein-RNA recognition in the RNAi pathway. Curr. Opin. Struct. Biol. 15:107-115.

Liu, J., Valencia-Sanchez, M. A., Hannon, G. J., and Parker, R. 2005. MicroRNA-dependent localization of targeted mRNAs to mammalian P-bodies. Nat. Cell Biol. 7:719-723.

Liu, J.-L., and Gall, J. G. 2007. U bodies are cytoplasmic structures that contain uridine-rich small nuclear ribonucleoproteins and associate with P bodies. Proc. Natl. Acad. Sci. U.S.A. 104:11655-11659.

Lloyd, R. E. 2015. Nuclear proteins hijacked by mammalian cytoplasmic plus strand RNA viruses. Virology 479-480:457-474.

Lloyd, R. E. 2016. Enterovirus control of translation and RNA granule stress responses. Viruses 8:93.

Love, A. J., Yu, C., Petukhova, N. V., Kalinina, N. O., Chen, J., and Taliansky, M. E. 2017. Cajal bodies and their role in plant stress and disease responses. RNA Biol. 14:779-790.

Lukhovitskaya, N. I., Cowan, G. H., Vetukuri, R. R., Tilsner, J., Torrance, L., and Savenkov, E. I. 2015. Importin- $\alpha$-mediated nucleolar localization of potato mop-top virus TRIPLE GENE BLOCK1 (TGB1) protein facilitates virus systemic movement, whereas TGB1 self-interaction is required for cell-to-cell movement in Nicotiana benthamiana. Plant Physiol. 167:738-752.

Lykke-Andersen, J. 2002. Identification of a human decapping complex associated with hUpf proteins in nonsense-mediated decay. Mol. Cell. Biol. 22:8114-8121.

Lykke-Andersen, J., and Wagner, E. 2005. Recruitment and activation of mRNA decay enzymes by two ARE-mediated decay activation domains in the proteins TTP and BRF-1. Genes Dev. 19:351-361.

Ma, X., Nicole, M. C., Meteignier, L. V., Hong, N., Wang, G., and Moffett, P. 2015. Different roles for RNA silencing and RNA processing components in virus recovery and virus-induced gene silencing in plants. J. Exp. Bot. 66:919-932. 
Machyna, M., Neugebauer, K. M., and Staněk, D. 2015. Coilin: The first 25 years. RNA Biol. 12:590-596.

Mäkinen, K., Lõhmus, A., and Pollari, M. 2017. Plant RNA regulatory network and RNA granules in virus infection. Front. Plant Sci. 8:2093.

Mao, Y. S., Zhang, B., and Spector, D. L. 2011. Biogenesis and function of nuclear bodies. Trends Genet. 27:295-306.

Martínez de Alba, A. E., Moreno, A. B., Gabriel, M., Mallory, A. C., Christ, A., Bounon, R., Balzergue, S., Aubourg, S., Gautheret, D., Crespi, M. D., Vaucheret, H., and Maizel, A. 2015. In plants, decapping prevents RDR6-dependent production of small interfering RNAs from endogenous mRNAs. Nucleic Acids Res. 43:2902-2913.

Martínez-Pérez, M., Aparicio, F., López-Gresa, M. P., Bellés, J. M., SánchezNavarro, J. A., and Pallás, V. 2017. Arabidopsis m ${ }^{6}$ A demethylase activity modulates viral infection of a plant virus and the $\mathrm{m}^{6} \mathrm{~A}$ abundance in its genomic RNAs. Proc. Natl. Acad. Sci. U.S.A. 114:10755-10760.

Matthews, J. D., and Frey, T. K. 2012. Analysis of subcellular G3BP redistribution during rubella virus infection. J. Gen. Virol. 93:267-274.

May, J. P., Yuan, X., Sawicki, E., and Simon, A. E. 2018. RNA virus evasion of nonsense-mediated decay. PLoS Pathog. 14:e1007459.

McInerney, G. M., Kedersha, N. L., Kaufman, R. J., Anderson, P., and Liljestrom, P. 2005. Importance of eIF2 $\alpha$ phosphorylation and stress granule assembly in alphavirus translation regulation. Mol. Biol. Cell 16:3753-3763.

Meteignier, L. V., Zhou, J., Cohen, M., Bhattacharjee, S., Brosseau, C., Chan, M. G., Robatzek, S., and Moffett, P. 2016. NB-LRR signaling induces translational repression of viral transcripts and the formation of RNA processing bodies through mechanisms differing from those activated by UV stress and RNAi. J. Exp. Bot. 67:2353-2366.

Mir, M. A., Duran, W. A., Hjelle, B. L., Ye, C., and Panganiban, A. T. 2008. Storage of cellular $5^{\prime}$ mRNA caps in P bodies for viral cap-snatching. Proc. Natl. Acad. Sci. U.S.A. 105:19294-19299.

Miyamoto, Y., Yamada, K., and Yoneda, Y. 2016. Importin $\alpha$ : A key molecule in nuclear transport and non-transport functions. J. Biochem. 160:69-75.

Moore, M. J. 2005. From birth to death: The complex lives of eukaryotic mRNAs. Science 309:1514-1518.

Morimoto, M., and Boerkoel, C. F. 2013. The role of nuclear bodies in gene expression and disease. Biology (Basel) 2:976-1033.

Moser, J. J., Eystathioy, T., Chan, E. K. L., and Fritzler, M. J. 2007. Markers of mRNA stabilization and degradation, and RNAi within astrocytoma GW bodies. J. Neurosci. Res. 85:3619-3631.

Nizami, Z., Deryusheva, S., and Gall, J. G. 2010a. The Cajal body and histone locus body. Cold Spring Harb. Perspect. Biol. 2:a000653.

Nizami, Z. F., Deryusheva, S., and Gall, J. G. 2010b. Cajal bodies and histone locus bodies in Drosophila and Xenopus. Cold Spring Harb. Symp. Quant. Biol. 75:313-320.

Noueiry, A. O., Diez, J., Falk, S. P., Chen, J., and Ahlquist, P. 2003. Yeast Lsm1p-7p/Pat1p deadenylation-dependent mRNA-decapping factors are required for brome mosaic virus genomic RNA translation. Mol. Cell. Biol. 23:4094-4106.

Okano, Y., Senshu, H., Hashimoto, M., Neriya, Y., Netsu, O., Minato, N., Yoshida, T., Maejima, K., Oshima, K., Komatsu, K., Yamaji, Y., and Namba, S. 2014. In planta recognition of a double-stranded RNA synthesis protein complex by a potexviral RNA silencing suppressor. Plant Cell 26:2168-2183.

Okonski, K. M., and Samuel, C. E. 2012. Stress granule formation induced by measles virus is protein kinase PKR dependent and impaired by RNA adenosine deaminase ADAR1. J. Virol. 87:756-766.

Onomoto, K., Jogi, M., Yoo, J. S., Narita, R., Morimoto, S., Takemura, A., Sambhara, S., Kawaguchi, A., Osari, S., Nagata, K., Matsumiya, T., Namiki, H., Yoneyama, M., and Fujita, T. 2012. Critical role of an antiviral stress granule containing RIG-I and PKR in viral detection and innate immunity. PLoS One 7:e43031.

Onomoto, K., Yoneyama, M., Fung, G., Kato, H., and Fujita, T. 2014. Antiviral innate immunity and stress granule responses. Trends Immunol. 35:420-428.

Orban, T. I., and Izaurralde, E. 2005. Decay of mRNAs targeted by RISC requires XRN1, the Ski complex, and the exosome. RNA 11:459-469.

Pager, C. T., Schütz, S., Abraham, T. M., Luo, G., and Sarnow, P. 2013. Modulation of hepatitis C virus RNA abundance and virus release by dispersion of processing bodies and enrichment of stress granules. Virology 435:472-484.

Panas, M. D., Varjak, M., Lulla, A., Eng, K. E., Merits, A., Karlsson Hedestam, G. B., and McInerney, G. M. 2012. Sequestration of G3BP coupled with efficient translation inhibits stress granules in Semliki Forest virus infection. Mol. Biol. Cell 23:4701-4712.

Parker, R., and Sheth, U. 2007. P bodies and the control of mRNA translation and degradation. Mol. Cell 25:635-646.

Patel, P. H., Barbee, S. A., and Blankenship, J. T. 2016. GW-bodies and Pbodies constitute two separate pools of sequestered non-translating RNAs. PLoS One 11:e0150291.
Pauley, K. M., Eystathioy, T., Jakymiw, A., Hamel, J. C., Fritzler, M. J., and Chan, E. K. L. 2006. Formation of GW bodies is a consequence of microRNA genesis. EMBO Rep. 7:904-910.

Pendle, A. F., Clark, G. P., Boon, R., Lewandowska, D., Lam, Y. W., Andersen, J., Mann, M., Lamond, A. I., Brown, J. W., and Shaw, P. J 2005. Proteomic analysis of the Arabidopsis nucleolus suggests novel nucleolar functions. Mol. Biol. Cell 16:260-269.

Peng, J., Yang, J., Yan, F., Lu, Y., Jiang, S., Lin, L., Zheng, H., Chen, H., and Chen, J. 2011. Silencing of NbXrn4 facilitates the systemic infection of Tobacco mosaic virus in Nicotiana benthamiana. Virus Res. 158:268-270.

Pérez-Cañamás, M., and Hernández, C. 2018. New insights into the nucleolar localization of a plant RNA virus-encoded protein that acts in both RNA packaging and RNA silencing suppression: Involvement of importins alpha and relevance for viral infection. Mol. Plant-Microbe Interact. 31:1134-1144.

Pfaff, C., Ehrnsberger, H. F., Flores-Tornero, M., Sørensen, B. B., Schubert, T., Längst, G., Griesenbeck, J., Sprunck, S., Grasser, M., and Grasser, K. D. 2018. ALY RNA-binding proteins are required for nucleocytosolic mRNA transport and modulate plant growth and development. Plan Physiol. 177:226-240.

Picó, S., Ortiz -Marchena, M. I., Merini, W., and Calonje, M. 2015. Deciphering the role of POLYCOMB REPRESSIVE COMPLEX1 variants in regulating the acquisition of flowering competence in Arabidopsis. Plant Physiol. 168:1286-1297.

Pillai, R. S., Bhattacharyya, S. N., Artus, C. G., Zoller, T., Cougot, N., Basyuk, E., Bertrand, E., and Filipowicz, W. 2005. Inhibition of translational initiation by Let-7 MicroRNA in human cells. Science 309:1573-1576.

Poblete-Durán, N., Prades-Pérez, Y., Vera-Otarola, J., Soto-Rifo, R., and Valiente-Echeverría, F. 2016. Who regulates whom? An overview of RNA granules and viral infections. Viruses 8:180

Pomeranz, M., Lin, P. C., Finer, J., and Jang, J. C. 2010. AtTZF gene family localizes to cytoplasmic foci. Plant Signal. Behav. 5:190-192.

Pontes, O., Li, C. F., Costa Nunes, P., Haag, J., Ream, T., Vitins, A., Jacobsen, S. E., and Pikaard, C. S. 2006. The Arabidopsis chromatinmodifying nuclear siRNA pathway involves a nucleolar RNA processing center. Cell 126:79-92.

Pontes, O., and Pikaard, C. S. 2008. siRNA and miRNA processing: New functions for Cajal bodies. Curr. Opin. Genet. Dev. 18:197-203.

Rajamäki, M. L., Streng, J., and Valkonen, J. P. 2014. Silencing suppressor protein VPg of a potyvirus interacts with the plant silencing-related protein SGS3. Mol. Plant-Microbe Interact. 27:1199-1210.

Rajamäki, M. L., and Valkonen, J. P. 2009. Control of nuclear and nucleolar localization of nuclear inclusion protein a of picorna-like potato virus A in Nicotiana species. Plant Cell 21:2485-2502.

Reineke, L. C., and Lloyd, R. E. 2013. Diversion of stress granules and Pbodies during viral infection. Virology 436:255-267.

Reyes, J. C. 2001. PML and COP1-Two proteins with much in common. Trends Biochem. Sci. 26:18-20.

Scherer, M., and Stamminger, T. 2016. Emerging role of PML nuclear bodies in innate immune signaling. J. Virol. 90:5850-5854.

Scholte, F. E. M., Tas, A., Albulescu, I. C., Žusinaite, E., Merits, A., Snijder, E. J., and van Hemert, M. J. 2015. Stress granule components G3BP1 and G3BP2 play a proviral role early in Chikungunya virus replication. J. Virol. 89:4457-4469.

Semashko, M. A., González, I., Shaw, J., Leonova, O. G., Popenko, V. I., Taliansky, M. E., Canto, T., and Kalinina, N. O. 2012. The extreme Nterminal domain of a hordeivirus TGB1 movement protein mediates its localization to the nucleolus and interaction with fibrillarin. Biochimie 94:1180-1188

Seo, J. S., Diloknawarit, P., Park, B. S., and Chua, N.-H. 2019. ELF18INDUCED LONG NONCODING RNA 1 evicts fibrillarin from mediator subunit to enhance PATHOGENESIS-RELATED GENE 1 (PRI) expression. New Phytol. 221:2067-2079.

Serman, A., Le Roy, F., Aigueperse, C., Kress, M., Dautry, F., and Weil, D. 2007. GW body disassembly triggered by siRNAs independently of their silencing activity. Nucleic Acids Res. 35:4715-4727.

Shaw, J., Love, A. J., Makarova, S. S., Kalinina, N. O., Harrison, B. D., and Taliansky, M. E. 2014. Coilin, the signature protein of Cajal bodies, differentially modulates the interactions of plants with viruses in widely different taxa. Nucleus 5:85-94.

Shaw, J., Yu, C., Makhotenko, A. V., Makarova, S. S., Love, A. J., Kalinina, N. O., MacFarlane, S., Chen, J., and Taliansky, M. E. 2019. Interaction of a plant virus protein with the signature Cajal body protein coilin facilitates salicylic acid-mediated plant defence responses. New Phytol. 224:439-453

Sheth, U., and Parker, R. 2003. Decapping and decay of messenger RNA occur in cytoplasmic processing bodies. Science 300:805-808.

Sheth, U., and Parker, R. 2006. Targeting of aberrant mRNAs to cytoplasmic processing bodies. Cell 125:1095-1109. 
Shyu, A. B., Wilkinson, M. F., and van Hoof, A. 2008. Messenger RNA regulation: To translate or to degrade. EMBO J. 27:471-481.

Song, L., Han, M. H., Lesicka, J., and Fedoroff, N. 2007. Arabidopsis primary microRNA processing proteins HYL1 and DCL1 define a nuclear body distinct from the Cajal body. Proc. Natl. Acad. Sci. U.S.A. 104:5437-5442.

Sorenson, R., and Bailey-Serres, J. 2014. Selective mRNA sequestration by OLIGOURIDYLATE-BINDING PROTEIN 1 contributes to translational control during hypoxia in Arabidopsis. Proc. Natl. Acad. Sci. U.S.A. 111:2373-2378.

Souret, F. F., Kastenmayer, J. P., and Green, P. J. 2004. AtXRN4 degrades mRNA in Arabidopsis and its substrates include selected miRNA targets. Mol. Cell 15:173-183.

Staněk, D. 2017. Cajal bodies and snRNPs_-Friends with benefits. RNA Biol. 14:671-679.

Steffens, A., Jaegle, B., Tresch, A., Hülskamp, M., and Jakoby, M. 2014. Processing-body movement in Arabidopsis depends on an interaction between myosins and DECAPPING PROTEIN1. Plant Physiol. 164:1879-1892.

Stępiński, D. 2014. Functional ultrastructure of the plant nucleolus. Protoplasma 251:1285-1306.

Stoecklin, G., and Kedersha, N. 2013. Relationship of GW/P-bodies with stress granules. Pages 197-211 in: Ten Years of Progress in GW/P Body Research. Advances in Experimental Medicine and Biology, Vol. 768. E. Chan and M. Fritzler, eds. Springer, New York, NY, U.S.A.

Takata, M. A., Gonçalves-Carneiro, D., Zang, T. M., Soll, S. J., York, A., Blanco-Melo, D., and Bieniasz, P. D. 2017. CG dinucleotide suppression enables antiviral defence targeting non-self RNA. Nature 550:124-127.

Taliansky, M. E., Brown, J. W. S., Rajamäki, M. L., Valkonen, J. P. T., and Kalinina, N. O. 2010. Involvement of the plant nucleolus in virus and viroid infections: Parallels with animal pathosystems. Adv. Virus Res. 77:119-158.

Teixeira, D., Sheth, U., Valencia-Sanchez, M. A., Brengues, M., and Parker, R. 2005. Processing bodies require RNA for assembly and contain nontranslating mRNAs. RNA 11:371-382.

Tharun, S., Muhlrad, D., Chowdhury, A., and Parker, R. 2005. Mutations in the Saccharomyces cerevisiae LSM1 gene that affect mRNA decapping and $3^{\prime}$ end protection. Genetics 170:33-46.

Thivierge, K., Cotton, S., Dufresne, P. J., Mathieu, I., Beauchemin, C., Ide, C., Fortin, M. G., and Laliberté, J. F. 2008. Eukaryotic elongation factor $1 \mathrm{~A}$ interacts with turnip mosaic virus RNA-dependent RNA polymerase and VPg-Pro in virus-induced vesicles. Virol. 377:216-225.

Thran, M., Link, K., and Sonnewald, U. 2012. The Arabidopsis DCP2 gene is required for proper mRNA turnover and prevents transgene silencing in Arabidopsis. Plant J. 72:368-377.

Trinkle-Mulcahy, L., and Sleeman, J. E. 2017. The Cajal body and the nucleolus: "In a relationship" or "It's complicated"? RNA Biol. 14: 739-751.

Tsai, W.-C., and Lloyd, R. E. 2014. Cytoplasmic RNA granules and viral infection. Annu. Rev. Virol. 1:147-170.

Tsuzuki, M., Motomura, K., Kumakura, N., and Takeda, A. 2017. Interconnections between mRNA degradation and RDR-dependent siRNA production in mRNA turnover in plants. J. Plant Res. 130: 211-226.

Uhrig, J. F., Canto, T., Marshall, D., and MacFarlane, S. A. 2004. Relocalization of nuclear ALY proteins to the cytoplasm by the tomato bushy stunt virus P19 pathogenicity protein. Plant Physiol. 135: 2411-2423.

Unterholzner, L., and Izaurralde, E. 2004. SMG7 acts as a molecular link between mRNA surveillance and mRNA decay. Mol. Cell 16: 587-596.

van Dijk, E., Cougot, N., Meyer, S., Babajko, S., Wahle, E., and Séraphin, B. 2002. Human Dcp2: A catalytically active mRNA decapping enzyme located in specific cytoplasmic structures. EMBO J. 21:6915-6924.

Wang, A., and Krishnaswamy, S. 2012. Eukaryotic translation initiation factor 4E-mediated recessive resistance to plant viruses and its utility in crop improvement. Mol. Plant Pathol. 13:795-803.

Wang, L., Tan, H., Wu, M., Jimenez-Gongora, T., Tan, L., and LozanoDuran, R. 2017. Dynamic virus-dependent subnuclear localization of the capsid protein from a geminivirus. Front. Plant Sci. 8:2165.

Wang, X., Chang, L., Wang, H., Su, A., and Wu, Z. 2017. Dcp1a and GW182 induce distinct cellular aggregates and have different effects on microRNA pathway. DNA Cell Biol. 36:565-570.

Weber, C., Nover, L., and Fauth, M. 2008. Plant stress granules and mRNA processing bodies are distinct from heat stress granules. Plant J. 56: 517-530.

White, J. P., and Lloyd, R. E. 2012. Regulation of stress granules in virus systems. Trends Microbiol. 20:175-183.

Xie, L., Lu, B., Zheng, Z., Miao, Y., Liu, Y., Zhang, Y., Zheng, C., Ke, X., $\mathrm{Hu}, \mathrm{Q}$., and Wang, H. 2018. The 3C protease of enterovirus A71 counteracts the activity of host zinc-finger antiviral protein (ZAP). J. Gen. Virol. 99:73-85.

$\mathrm{Xu}$, J., and Chua, N. H. 2009. Arabidopsis decapping 5 is required for mRNA decapping, P-body formation, and translational repression during postembryonic development. Plant Cell 21:3270-3279.

Xu, J., and Chua, N. H. 2011. Processing bodies and plant development. Curr. Opin. Plant Biol. 14:88-93.

Xu, J., Yang, J. Y., Niu, Q. W., and Chua, N. H. 2006. Arabidopsis DCP2, DCP1, and VARICOSE form a decapping complex required for postembryonic development. Plant Cell 18:3386-3398.

Ye, J., Yang, J., Sun, Y., Zhao, P., Gao, S., Jung, C., Qu, J., Fang, R., and Chua, N. H. 2015. Geminivirus activates ASYMMETRIC LEAVES 2 to accelerate cytoplasmic DCP2-mediated mRNA turnover and weakens RNA silencing in Arabidopsis. PLoS Pathog. 11:e1005196.

Zhang, X., Yuan, Y. R., Pei, Y., Lin, S. S., Tuschl, T., Patel, D. J., and Chua, N. H. 2006. Cucumber mosaic virus-encoded 2b suppressor inhibits Arabidopsis Argonaute1 cleavage activity to counter plant defense. Genes Dev. 20:3255-3268.

Zhang, X.-P., Liu, D.-S., Yan, T., Fang, X.-D., Dong, K., Xu, J., Wang, Y., Yu, J.-L., and Wang, X.-B. 2017. Cucumber mosaic virus coat protein modulates the accumulation of $2 \mathrm{~b}$ protein and antiviral silencing that causes symptom recovery in planta. PLoS Pathog. 13: e1006522.

Zheng, L., Du, Z., Lin, C., Mao, Q., Wu, K., Wu, J., Wei, T., Wu, Z., and $\mathrm{Xie}$, L. 2015. Rice stripe tenuivirus p2 may recruit or manipulate nucleolar functions through an interaction with fibrillarin to promote virus systemic movement. Mol. Plant Pathol. 16:921-930.

Zhou, M., and Law, J. A. 2015. RNA Pol IV and V in gene silencing: Rebel polymerases evolving away from Pol II's rules. Curr. Opin. Plant Biol. 27:154-164. 